\title{
Assessing Soil Nutrients Variability and Adequacy for the Cultivation of Maize, Cassava, and Sorghum in Selected Agroecological Zones of Cameroon
}

\author{
Lawrence T. Nanganoa ${ }^{D},{ }^{1}$ Francis A. Ngome, ${ }^{2}$ Christopher Suh, ${ }^{2}$ and Simon D. Basga ${ }^{3}$ \\ ${ }^{1}$ Institute of Agricultural Research for Development (IRAD), PMB. 25, Buea, Cameroon \\ ${ }^{2}$ Institute of Agricultural Research for Development (IRAD), P.O. Box 2123, Yaounde, Cameroon \\ ${ }^{3}$ Institute of Agricultural Research for Development (IRAD), P.O. Box 415, Garoua, Cameroon \\ Correspondence should be addressed to Lawrence T. Nanganoa; tatanah2002@yahoo.fr
}

Received 26 June 2020; Revised 10 December 2020; Accepted 14 December 2020; Published 28 December 2020

Academic Editor: Othmane Merah

Copyright $\odot 2020$ Lawrence T. Nanganoa et al. This is an open access article distributed under the Creative Commons Attribution License, which permits unrestricted use, distribution, and reproduction in any medium, provided the original work is properly cited.

\begin{abstract}
Access to information on soil nutrients status and variability is essential in understanding the potential of soils and their responsiveness to management interventions in agriculture. The current study evaluated soil nutrients status in selected agroecological zones (AEZs) of Cameroon and identified variations and their adequacy for maize (Zea mays L.), sorghum (Sorghum bicolor L. (Moench)), and cassava (Manihot esculenta Crantz) production. A total of 163 soil samples were collected from surface $(0-15 \mathrm{~cm})$ layer for the determination of $\mathrm{pH}$, organic matter $(\mathrm{OM})$, estimated nitrogen release (ENR), sulphur (S), calcium (Ca), magnesium $(\mathrm{Mg})$, potassium $(\mathrm{K})$, sodium $(\mathrm{Na})$, boron $(\mathrm{B})$, iron $(\mathrm{Fe})$, manganese $(\mathrm{Mn})$, copper $(\mathrm{Cu})$, zinc $(\mathrm{Zn})$, aluminium $(\mathrm{Al})$, phosphorus (P), total exchangeable capacity (TEC), and base saturations. The results showed different degrees of variability in soil nutrients ranging from low to very high in all the AEZs. The soils in all the AEZs were consistently deficient in available phosphorus, sulphur, boron, and zinc in varying proportion and might be inadequate to supply cultivated maize, sorghum, and cassava with the nutrients needed to achieve optimal growth. The soils were also prone to Mg-induced K deficiency, which could limit the growth of maize, sorghum, or cassava. These results therefore suggest that management of inherent soil properties should be based on-site specific situations.
\end{abstract}

\section{Introduction}

Environmental degradation is a worldwide problem caused by inappropriate cropping system and land-use and soil management practices and has attracted attention in sustainable agricultural production systems [1-3]. Soil quality degradation is among the top development challenges that demand urgent remedial actions [3, 4]. In Cameroon, the rapid rise in population has led to increase pressure on available arable land. This has resulted in land degradation and subsequent soil fertility decline because of increasingly intense land use without sufficient organic and mineral inputs [5]. Under intensive farming systems, crops grown with inadequate supply of nutrients cause soil fertility deterioration and the emergence of multinutrient deficiencies in many places $[6,7]$. Soil fertility status is thus the mainstay on which all input-based high agricultural production systems can be built [8].

Feeding the ever-growing population where low soil fertility is a primary constraint to food production is a serious challenge $[9,10]$. Thus, to reduce soil fertility-related constraints, there is need for the encouragement of soil fertility management practices which include promotion of organic manure and compost, green manuring, and balanced use of chemical fertilizers [11-13]. However, soil fertility management cannot be fostered without an appropriate and rapid assessment of soil nutrients status so that decision makers and farmers can be aware of the soil fertility constraints and then make informed decisions to 
improve crop yields and better manage soil nutrients [14]. Other countries such as India in 2012, Kenya and Nepal in 2014 [12], and recently Cameroon have adopted the use of soil-testing mobile vans for farmers to have their soil tested for nutrient deficiencies and fertilizer requirements. Regardless of their present drawbacks, chemical methods of agricultural soil testing are the most frequently used diagnostic tools of soil nutrient status and the need of fertilization derived from it [15].

Information on soil nutrients status is still very scarce and also much localized [16-21]. Therefore, the agroecological zone (AEZ) approach is needed for assessing and understanding the soil nutrients status at a much larger scale in order to provide farmers with information and recommendations that will improve agricultural productivity. There is an immense dependence of agriculture productivity on soil physicochemical properties. These properties vary widely with soil types, which in turn control water and nutrient uptake by plants $[22,23]$. Cameroon is divided into five agroecological zones (AEZs) and is distinguishable by dominant physical, climatic, and vegetative features. The climate varies with terrain, from tropical along the coast to semiarid and hot in the North [24]. Altitude plays a significant role in changing the climatic characteristics, soil properties, and land-use patterns. This further drives the soil microbial functions and nutrient interaction with plants [25]. Since altitudinal gradient directly affects the soil characteristics which in turn affect soil-water-plant relationship, measurements of the spatial variability in soil properties are also crucial [23]. Information on the spatial distribution of soil properties within a field to larger landscapes, regions, and/or AEZs is a prerequisite for best management decisions such as selection of appropriate fertilizer dose, methods, and frequency of its application [26].

So far, in Cameroon, fertilizer trails were conducted on few research stations and no effort was made to extrapolate the results to a wider range of environments. This could be one of the reasons of the yield variation in food crops in the different agroecological zones [27] as soil chemical properties are found to be variable and change rapidly. The crop yield gaps could therefore be related to inadequate replenishment and improper management of soil nutrients [24]. In this regard, the objectives of this study were to evaluate nutrients status of soils in selected agroecological zones and identify variations and their adequacy for maize, sorghum, and cassava production. Relationships between soil chemical properties were also studied.

\section{Materials and Methods}

2.1. Description of Study Area. Cameroon lies in sub-Saharan Africa, located on the Gulf of Guinea, between latitudes $1.7^{\circ} \mathrm{N}-13.8^{\circ} \mathrm{N}$ and longitudes $8.4^{\circ} \mathrm{E}-16.8^{\circ} \mathrm{E}$. It has five major agroecological zones (AEZs) (Figure 1) [24]. The study areas were located in four AEZs and are as follows.

Sudano-Sahelian (AEZ 1) with maize, millet-sorghum, groundnut, rice, cowpea, soybean, onion, sesame, fruits, and cotton as the main crops produced is made up of low altitude plain, many of which are flooded during the rainy season, which lasts for about 4 months (June-September) and a few gentle dune slopes [28]. The dry season is very pronounced and runs for about eight months extending from October to May. The mean annual rainfall and the mean annual air temperature in the area are $800 \mathrm{~mm}$ and $29^{\circ} \mathrm{C}$, respectively [29]. Vegetation cover is dry savannah strongly degraded and converted into agricultural lands with few native species. The major soil groups in this area are as follows: Lixisols, Luvisols, Vertisols, Regosols, Fluvisols, Gleysols, Leptosols, Planosols, Plinthosols, and Arenosols.

High Guinea Savannah (AEZ 2) with maize, yam, cassava, sweet potatoes, rice, and bean as the main cultivated crops consists of a high plateau (average altitude is $1100 \mathrm{~m}$ ) and mean annual temperature of $23^{\circ} \mathrm{C}$. The dry season lasts for 4 to 6 months, and the main soil groups present are Nitisols, Ferralsols, Acrisols, Luvisols, Leptosols, and Cambisols.

Western Highlands (AEZ 3) with maize, beans, potatoes, rice, sweet potatoes, vegetables, and coffee as the major crops produced features many high plateaus (1000-1800 m) and very high altitude mountains. Annual rainfall generally exceeds $2000 \mathrm{~mm}$, and the mean annual temperature is $21^{\circ} \mathrm{C}$. The main soil groups present here are Ferralsols, Nitisols, Gleysols, Andosols, Cambisols, and Leptosols.

Bimodal Humid Forest (AEZ 5) with plantain, cassava, banana, maize, cocoyam, sweet potatoes, cocoa, oil palm, rubber, coffee, maize, and fruits are the main crops produced. This region is made up of a vast low altitude plain (mean altitude is $650 \mathrm{~m}$ ). It is characterized by green forest vegetation and by abundant precipitations. There are basically 2 rainy and 2 dry seasons and a mean annual temperature of $25^{\circ} \mathrm{C}$. The various soil groups in this area are Ferralsols, Nitisols, Acrisols, Gleysols, Fluvisols, and Andosols [28].

2.2. Soil Sampling, Processing, and Physicochemical Analysis. In all the selected sites, 163 composite soil samples were collected with an auger from top soils $(0-15 \mathrm{~cm})$ of agriculturally farmed fields and fallow lands in 27 localities span in 4 AEZs in Cameroon, namely, (1) Sudano-Sahelian, (2) High Guinea Savannah, (3) Western Highlands, and (4) Humid Forest with bimodal rainfall pattern (Figure 1 and Table 1). Each composite sample was formed by bulking 15 subsamples. The previous land uses at the different sites are shown in Figure 1 and Table 1. Out of the 163 composite soil samples collected from the study sites, 62 were from localities in the Far North (AEZ 1), 46 in the North (AEZ 1), 18 in the Centre (AEZ 5), 32 in Adamawa (AEZ 2), and 5 in the West region (AEZ 3) (Table 1). These sites were chosen because food production here is still largely in the hands of smallholder farmers/groups whose cultivation practices continue to be characterized by the use of basic tools, low fertilizer inputs, limited control of plant pests and diseases, and low yield. The soil samples were air-dried and sieved through $2 \mathrm{~mm}$ screen to remove stones and plant debris and then sent to the Brookside Laboratories INC, New Bremen, USA, for analysis. Soil $\mathrm{pH}$ was determined in the ratio of $1: 1$ 
soil-water suspensions using a digital $\mathrm{pH}$ meter [30]. OM (\%) was determined by loss on ignition method at $360^{\circ} \mathrm{C}$ [31] and ENR (lbs acre ${ }^{-1}$ ) which is a computed estimate of nitrogen that may be released annually through organic matter decomposition calculated based on the loss on ignition method. S (ppm), Ca (mg kg$\left.{ }^{-1}\right), \mathrm{Mg}\left(\mathrm{mg} \mathrm{kg}^{-1}\right), \mathrm{K}\left(\mathrm{mg} \mathrm{kg}^{-1}\right)$, $\mathrm{Na}\left(\mathrm{mg} \mathrm{kg}^{-1}\right), \mathrm{B}\left(\mathrm{mg} \mathrm{kg}^{-1}\right), \mathrm{Fe}\left(\mathrm{mg} \mathrm{kg}^{-1}\right), \mathrm{Mn}\left(\mathrm{mg} \mathrm{kg}^{-1}\right), \mathrm{Cu}$ $\left(\mathrm{mg} \mathrm{kg}^{-1}\right), \mathrm{Zn}\left(\mathrm{mg} \mathrm{kg}^{-1}\right), \mathrm{Al}\left(\mathrm{mg} \mathrm{kg}^{-1}\right)$, and $\mathrm{P}\left(\mathrm{mg} \mathrm{kg}^{-1}\right)$ were determined after extraction with Mehlich-3 solution [32]. Mehlich-3 multinutrient soil extraction method was adopted in this study because it is cost-effective, less time-consuming, extracts multiple nutrients, and is being used by many regional organizations [33]. TEC (meq/100 g) was obtained by summation of the cations [34]. The base ( $\mathrm{Ca}, \mathrm{Mg}, \mathrm{K}$, and $\mathrm{Na}$ ) saturations (\%) were calculated as the percentage of soils total exchange capacity occupied by the base cation for any given sample. Available phosphorus (P) was also determined by the Bray II method [35].

2.3. Data Analysis. The data were subjected to statistical analysis using Microsoft Excel 2016 and SPSS statistical package 25.0. Soil nutrients level in the samples was analyzed using descriptive statistics (means, standard deviations, minimum and maximum values, skewness, and kurtosis) and their variability assessed using coefficient of variation (CV). Less than $20 \% \mathrm{CV}$ is regarded as low variability, between 20 and $50 \% \mathrm{CV}$ is regarded as moderate variability, and between 50 and $100 \%$ $\mathrm{CV}$ is regarded as high variability. Any CV above $100 \%$ is regarded as very high variability [36]. The mean, standard deviation, skewness, kurtosis, and CV were not computed for soil nutrients with one or more measurements below the limit of quantification (for example, $(\mathrm{S}$ and $\mathrm{P})<1$; $\mathrm{B}<0.2$, and $\left.\mathrm{Zn}<0.4 \mathrm{mg} \mathrm{kg}^{-1}\right)$. The hypothesis of data normality was verified by the Shapiro-Wilk test. To compare the variability in soil parameters among the regions, nonparametric analyses were applied, using the Kruskal-Wallis and Mann-Whitney $U$ tests to determine the significance of differences since majority of the soil properties did not have normal distributions; Box and Whisker plots were drawn, and here the measurements of the physicochemical properties below the limit of quantification were set at zero. Based on critical values of soil nutrients established for the soil nutrient extraction methods used in this study, the soil nutrients were rated very low, low, medium, high, or very high. The adequacy of these soil nutrients for the cultivation of maize (in all the sites), sorghum (in the sites examined in the Far North and North regions), and cassava (in the study sites of Adamawa and Centre regions) was assessed by comparing the soil nutrients to the critical value or range recommended for optimal maize, sorghum, and cassava growth and yield. Correlations among the soil properties were checked by Spearman's correlation coefficient. Also measurements of soil properties less than the limits of quantification were eliminated in the calculations.

\section{Results and Discussion}

3.1. Summary Statistics of Soil Properties. The summary of the descriptive statistical data of the chemical properties of soil samples in selected AEZs of Cameroon grouped according to regions is presented in Tables 2-6. The results showed the complexity of soil nutrients variability within the regions. Most of the chemical properties showed positive skewness in all the regions except for the West region with an important number of negative skewness (Table 6). The kurtosis was also highly variable, with some values greater than 1 or less than -1 (Tables $2-6$ ). The highest value of Kurtosis coefficient was for $\mathrm{Na}$ base saturation data in the Far North (Table 2). By the Shapiro-Wilk statistical measurement at $P<0.05$, it was found that most of the data in the Far North, North and Adamawa regions had nonnormal distribution (Tables 2, 3, and 5). However, most of the data for Centre and West regions had normal distribution (Tables 4 and 6).

The $\mathrm{CV}$ was less variable for soil $\mathrm{pH}$ in all the regions (Tables 2-6). This variability was similar to those reported by other authors $[37,38]$. Soil pH is one of the soil physicochemical properties that influence the availability of plant nutrients. Although the variability reported for $\mathrm{pH}$ was low for all the regions, small changes in $\mathrm{pH}$ value have significant effects on nutrient availability. CV was also low for soil $\mathrm{Ca}$ base saturation in the Far North region. The concentration of $\mathrm{Na}$ in soil samples in the Centre region and $\mathrm{S}, \mathrm{Ca}, \mathrm{Mg}, \mathrm{K}, \mathrm{Na}$, and $\mathrm{Al}$ in the West region also had low $\mathrm{CV}$.

The moderate to very high CVs for most of the soil properties revealed considerable variability which could be attributed to inherent soil forming factors and management practices of various crops that alter the inherent spatial structure of soil properties [26,39]. It is therefore suggested that site-specific nutrients management to improve soil productivity in the sampling locations be applied.

\subsection{Soil Chemical Properties}

3.2.1. Soil $p H$. Soil $\mathrm{pH}-\mathrm{H}_{2} \mathrm{O}$ for samples in the Far North region ranged from 5.10 to 8.90 (Table 2) with the majority of soils in the acidic to neutral $\mathrm{pH}$ range. About $16.13 \%$, $14.52 \%, 22.58 \%, 35.48 \%, 4.84 \%, 3.23 \%$, and $3.23 \%$ of the soil samples from this area were categorized as strongly acidic ( $\mathrm{pH}$ 5.1-5.5), moderately acidic (5.6-6.0), slightly acidic (6.1-6.5), neutral (6.6-7.3), slightly alkaline (7.4-7.8), moderately alkaline (7.9-8.4), and strongly alkaline (8.5-9.0), respectively, as per the ratings of the United State Department of Agriculture Natural Resources conservation classification of soil pH [40]. For soil samples in the North region, $\mathrm{pH}$ was found to range from acidic to neutral $(\mathrm{pH}$ 4.7-7.5) (Table 3). About 8.70\%, 32.61\%, 32.61\%, 10.87\%, $13.04 \%$, and $2.17 \%$ of the soil samples were rated as very strongly acidic (4.5-5.0), strongly acidic, moderately acidic, slightly acidic, and neutral and slightly alkaline, respectively. For soil samples in the Centre, Adamawa, and West regions, all the $\mathrm{pH}$ values were acidic and ranged from 3.9 to 6.0 for Centre, 4.2 to 6.0 for Adamawa, and 4.8 to 6.2 for the West region (Tables $4-6$ ). About $27.78 \%$ of soil samples in the Centre region and $37.5 \%$ in the Adamawa were extremely acidic ( $\mathrm{pH} 3.5-4.4$ ). 33.33\% of soil samples in the Centre, $37.5 \%$ in the Adamawa, and $20 \%$ in the West were very 


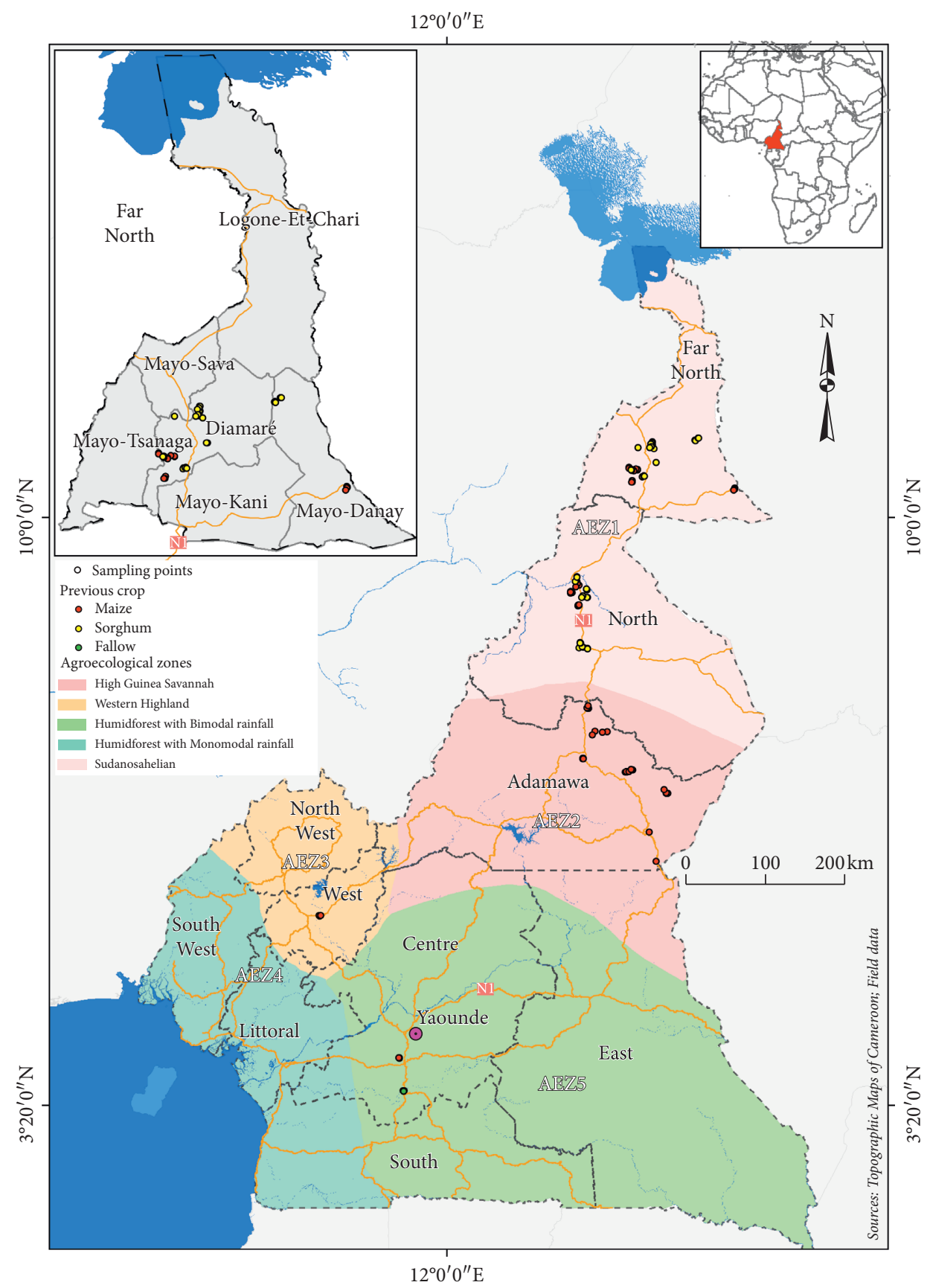

FIGURE 1: Location of the sampling points and locations in the different agroecological zones of Cameroon. AEZ, agroecological zone.

strongly acidic. $22.22 \%$ of soil in the Centre, $9.38 \%$ in Adamawa, and $20 \%$ in West region were strongly acidic, whereas $16.67 \%$ in Centre, $15.63 \%$ in Adamawa, and $40 \%$ in West were moderately acidic soils. Also $20 \%$ of the soil samples in West region were slightly acid. The optimum $\mathrm{pH}$ range for most agricultural crops is between 5.5 and 7.5. Thus, $79.03 \%$ of soils samples in Far North, $67.39 \%$ in North, $22.22 \%$ in Centre, $18.75 \%$ in Adamawa, and 60\% in West region were favourable for most crops. However, $\mathrm{pH}$ of acidic soil can be increased by using finely ground agricultural lime (limestone or chalk), wood ash, industrial calcium oxide (burnt lime), magnesium oxide, basic slag (calcium silicate), and oyster shells. On the contrary, the $\mathrm{pH}$ of alkaline soils can be decreased by using acidifying fertilizers (ammonium sulphate, ammonium nitrate, and urea) or organic materials (peat or sphagnum peat moss) [41].

Solubility and toxicity of aluminium in soils is very dependent on soil pH. Mehlich-3 method, however, does not determine the likelihood of aluminium toxicity but measures the dilute acid soluble $\mathrm{Al}$ that is Al likely to fix applied soluble P. High Mehlich-Al (>1500 mg/kg) [42, 43] can be taken to indicate high phosphate fixation and consequently good sulphate retention. Conversely, a low Mehlich-Al $(<900 \mathrm{mg} / \mathrm{kg})$ indicates a lower anion retention and the potential for greater leaching losses of sulphate. $100 \%$ of soil samples in the Far North, North, and West regions had 
TABLE 1: Sampling sites used for the study.

\begin{tabular}{|c|c|c|c|c|c|c|}
\hline No. & Locality & No. of samples & Division & Region & Previous crop & Agroecological zone \\
\hline 1 & Gazawa & 10 & Diamaré & Far North & Maize & \multirow{18}{*}{ Sudano-Sahelian (AEZ 1) } \\
\hline 2 & Mokong & 3 & Mayo Tsanaga & Far North & Maize & \\
\hline 3 & Gawel & 3 & Diamaré & Far North & Maize & \\
\hline 4 & Guiring & 3 & Diamaré & Far North & Sorghum & \\
\hline 5 & Guirvidig & 10 & Diamaré & Far North & Sorghum & \\
\hline 6 & Soukoungo & 5 & Diamaré & Far North & Sorghum & \\
\hline 7 & Salak & 10 & Diamaré & Far North & Sorghum & \\
\hline 8 & Papata & 5 & Diamaré & Far North & Sorghum & \\
\hline 9 & Dogba & 8 & Diamaré & Far North & Sorghum & \\
\hline 10 & Yagoua & 5 & Mayo Danay & Far North & Maize & \\
\hline 11 & Sangueré Paul & 5 & Benoué & North & Maize & \\
\hline 12 & Bibol & 10 & Benoué & North & Maize & \\
\hline 13 & Djalingo & 4 & Benoué & North & Maize & \\
\hline 14 & Gouna & 9 & Benoué & North & Sorghum & \\
\hline 15 & Karewa & 3 & Benoué & North & Sorghum & \\
\hline 16 & Kismatari & 5 & Benoué & North & Sorghum & \\
\hline 17 & Bamé & 5 & Benoué & North & Sorghum & \\
\hline 18 & Ngong & 5 & Benoué & North & Maize & \\
\hline 19 & Nkolbisson & 3 & Mfoundi & Centre & Maize & \multirow{2}{*}{ Bimodal Humid Forest (AEZ 5) } \\
\hline 20 & Mbalmayo 1 & 15 & Mefou Afamba & Centre & Fallow & \\
\hline 21 & Wassande & 9 & Vina & Adamawa & Maize & \multirow{6}{*}{ High Guinea Savannah (AEZ 2} \\
\hline 22 & Bellel & 5 & Mbere & Adamawa & Maize & \\
\hline 23 & Mbe & 5 & Vina & Adamawa & Maize & \\
\hline 24 & Meiganga & 3 & Mbere & Adamawa & Maize & \\
\hline 25 & Ngangasao & 5 & Vina & Adamawa & Maize & \\
\hline 26 & Wakwa & 5 & Vina & Adamawa & Maize & \\
\hline 27 & Mangoum & 5 & Noun & West & Maize & Western Highlands (AEZ 3) \\
\hline
\end{tabular}

TABle 2: Summary statistics of soil chemical properties within Far North region $(n=62)$.

\begin{tabular}{|c|c|c|c|c|c|c|c|c|}
\hline Soil properties & Max & Min & Mean & $\mathrm{SD}$ & $\mathrm{CV}(\%)$ & Kurtosis & Skewness & Shapiro-Wilk ( $P$ value) \\
\hline TEC (100 meq/100 g) & 35.4 & 3.80 & 16.09 & 7.79 & 48.41 & -0.04 & 0.78 & 0.002 \\
\hline $\mathrm{pH}$ & 8.9 & 5.10 & 6.50 & 0.84 & 12.95 & 0.49 & 0.63 & 0.049 \\
\hline Organic matter $(\%)$ & 1.96 & 0.26 & 0.95 & 0.40 & 41.70 & 0.30 & 0.83 & 0.005 \\
\hline Estimated $\mathrm{N}$ release (lbs acre $\mathrm{e}^{-1}$ ) & 59 & 10 & 35.26 & 11.59 & 32.87 & -0.63 & 0.11 & 0.38 \\
\hline$S(p p m)$ & 11 & 1 & 5.71 & 1.89 & 33.17 & 0.94 & 0.28 & 0.011 \\
\hline $\mathrm{P}\left(\mathrm{mg} \mathrm{kg}^{-1}\right)$ & 120 & $<1$ & - & - & - & - & - & - \\
\hline $\mathrm{Ca}\left(\mathrm{mg} \mathrm{kg}^{-1}\right)$ & 4251 & 291 & 1990.71 & 1039.62 & 52.22 & -0.56 & 0.54 & 0.013 \\
\hline $\mathrm{Mg}\left(\mathrm{mg} \mathrm{kg}^{-1}\right)$ & 1003 & 72 & 355.03 & 221.59 & 62.41 & 0.83 & 1.13 & 0.000 \\
\hline $\mathrm{K}\left(\mathrm{mg} \mathrm{kg}^{-1}\right)$ & 600 & 66 & 159.34 & 83.66 & 52.50 & 11.73 & 2.73 & 0.000 \\
\hline $\mathrm{Na}\left(\mathrm{mg} \mathrm{kg}^{-1}\right)$ & 695 & 12 & 74.19 & 118.19 & 159.30 & 19.93 & 4.28 & 0.000 \\
\hline $\mathrm{Al}\left(\mathrm{mg} \mathrm{kg}^{-1}\right)$ & 825 & 193 & 470.24 & 149.20 & 31.73 & -0.23 & 0.46 & 0.116 \\
\hline Ca saturation (\%) & 80.20 & 35.25 & 60.78 & 11.09 & 18.24 & -0.32 & -0.74 & 0.001 \\
\hline Mg saturation (\%) & 26.84 & 10.43 & 17.56 & 3.65 & 20.79 & -0.09 & 0.34 & 0.678 \\
\hline $\mathrm{K}$ saturation $(\%)$ & 9.19 & 0.92 & 2.92 & 1.68 & 57.47 & 4.07 & 1.96 & 0.000 \\
\hline $\mathrm{Na}$ saturation $(\%)$ & 25.74 & 0.50 & 2.02 & 3.54 & 174.78 & 35.07 & 5.60 & 0.000 \\
\hline $\mathrm{H}(\%)$ & 42 & 0.00 & 11.68 & 12.25 & 104.86 & -0.04 & 1.05 & 0.000 \\
\hline $\mathrm{B}\left(\mathrm{mg} \mathrm{kg}^{-1}\right)$ & 0.73 & $<0.2$ & - & - & - & - & - & - \\
\hline $\mathrm{Fe}\left(\mathrm{mg} \mathrm{kg}^{-1}\right)$ & 177 & 54 & 102.34 & 30.97 & 30.26 & 0.265 & 0.74 & 0.002 \\
\hline $\mathrm{Mn}\left(\mathrm{mg} \mathrm{kg}^{-1}\right)$ & 191 & 29 & 84.69 & 38.89 & 45.91 & -0.319 & 0.60 & 0.009 \\
\hline $\mathrm{Cu}\left(\mathrm{mg} \mathrm{kg}^{-1}\right)$ & 2.83 & 0.41 & 1.25 & 0.58 & 46.19 & -0.068 & 0.72 & 0.007 \\
\hline $\mathrm{Zn}\left(\mathrm{mg} \mathrm{kg}^{-1}\right)$ & 3.46 & $<0.4$ & - & - & - & - & - & - \\
\hline
\end{tabular}

Min: minimum; Max: maximum; SD: standard deviation; CV: coefficient of variation; values with "<" indicate the limit of quantification.

Mehlich-Al $<900 \mathrm{mg} / \mathrm{kg}$, while $77.78 \%$ and $21.88 \%$ of soils in the Centre and Adamawa regions had Mehlich-Al $<900 \mathrm{mg}$ / $\mathrm{kg}$ (actual soil $\mathrm{pH}$ values and chemical properties of the sampling sites are given in Tables $1 \mathrm{~S}-5 \mathrm{~S}$ of the Supplementary Material).
3.2.2. Organic Matter and Estimated Nitrogen Release. The OM contents were in the range of $0.26-1.96 \%$, $0.38-1.85 \%, 1.99-8.16 \%, 0.6-16.29 \%$, and $0.36-0.91 \%$ on the surface soil samples in the Far North, North, Centre, Adamawa, and West regions, respectively (Tables 2-6). 
TABLE 3: Summary statistics of soil chemical properties within North region $(n=46)$.

\begin{tabular}{|c|c|c|c|c|c|c|c|c|}
\hline Soil properties & Max & Min & Mean & $\mathrm{SD}$ & $\mathrm{CV}$ & Kurtosis & Skewness & Shapiro-Wilk ( $P$ value) \\
\hline TEC $(100 \mathrm{meq} / 100 \mathrm{~g})$ & 35.08 & 2.08 & 7.49 & 6.01 & 80.25 & 9.86 & 2.85 & 0.000 \\
\hline $\mathrm{pH}$ & 7.5 & 4.7 & 5.80 & 0.66 & 11.39 & 0.16 & 0.83 & 0.015 \\
\hline Organic matter $(\%)$ & 1.85 & 0.38 & 0.78 & 0.32 & 41.59 & 1.19 & 1.07 & 0.001 \\
\hline Estimated $\mathrm{N}$ release (lbs acre $\mathrm{e}^{-1}$ ) & 57 & 15 & 29.96 & 10.67 & 36.03 & 1.19 & 0.48 & 0.005 \\
\hline$S(p p m)$ & 7 & $<1.00$ & - & - & - & - & - & - \\
\hline $\mathrm{P}\left(\mathrm{mg} \mathrm{kg}^{-1}\right)$ & 111 & 2.00 & 12.11 & 18.55 & 153.16 & 21.15 & 4.50 & 0.000 \\
\hline $\mathrm{Ca}\left(\mathrm{mg} \mathrm{kg}^{-1}\right)$ & 4232 & 213 & 814.46 & 751.03 & 90.67 & 9.70 & 2.85 & 0.000 \\
\hline $\operatorname{Mg}\left(\mathrm{mg} \mathrm{kg}^{-1}\right)$ & 1140 & 25 & 136.02 & 190.29 & 139.90 & 18.07 & 3.99 & 0.000 \\
\hline $\mathrm{K}\left(\mathrm{mg} \mathrm{kg}^{-1}\right)$ & 183 & 30 & 72.78 & 30.25 & 41.57 & 2.82 & 1.46 & 0.000 \\
\hline $\mathrm{Na}\left(\mathrm{mg} \mathrm{kg}^{-1}\right)$ & 166 & 8 & 25.63 & 27.63 & 107.80 & 14.98 & 3.51 & 0.000 \\
\hline $\mathrm{Al}\left(\mathrm{mg} \mathrm{kg}^{-1}\right)$ & 698 & 202 & 379.07 & 116.34 & 30.34 & 0.17 & 0.76 & 0.048 \\
\hline Ca saturation (\%) & 74.59 & 28.77 & 52.39 & 11.68 & 22.30 & -0.87 & -0.08 & 0.476 \\
\hline Mg saturation (\%) & 27.08 & 7.52 & 12.94 & 4.46 & 34.46 & 1.65 & 1.35 & 0.000 \\
\hline $\mathrm{K}$ saturation $(\%)$ & 5.71 & 1.23 & 3.03 & 1.13 & 37.24 & -0.35 & 0.46 & 0.233 \\
\hline $\mathrm{Na}$ saturation (\%) & 5.94 & 0.63 & 1.54 & 0.92 & 59.79 & 10.92 & 2.72 & 0.000 \\
\hline $\mathrm{H}(\%)$ & 51 & 0.00 & 24.11 & 14.33 & 58.61 & -0.89 & -0.13 & 0.141 \\
\hline $\mathrm{B}\left(\mathrm{mg} \mathrm{kg}^{-1}\right)$ & 0.80 & $<0.2$ & - & - & - & - & - & - \\
\hline $\mathrm{Fe}\left(\mathrm{mg} \mathrm{kg}^{-1}\right)$ & 297 & 41 & 104.13 & 59.94 & 56.76 & 2.06 & 1.47 & 0.000 \\
\hline $\mathrm{Mn}\left(\mathrm{mg} \mathrm{kg}^{-1}\right)$ & 252 & 16 & 103.26 & 50.88 & 49.27 & 0.98 & 0.99 & 0.013 \\
\hline $\mathrm{Cu}\left(\mathrm{mg} \mathrm{kg}^{-1}\right)$ & 3.01 & 0.24 & 1.02 & 0.75 & 73.10 & 0.68 & 1.29 & 0.000 \\
\hline $\mathrm{Zn}\left(\mathrm{mg} \mathrm{kg}^{-1}\right)$ & 5.36 & $<0.4$ & - & - & - & - & - & - \\
\hline
\end{tabular}

Min: minimum; Max: maximum; SD: standard deviation; CV: coefficient of variation; values with "<" indicate the limit of quantification.

TABle 4: Summary statistics of soil chemical properties within Centre region $(n=18)$.

\begin{tabular}{|c|c|c|c|c|c|c|c|c|}
\hline Soil properties & Max & Min & Mean & SD & $\mathrm{CV}$ & Kurtosis & Skewness & Shapiro-Wilk ( $P$ value) \\
\hline TEC (100 meq/100 g) & 12.77 & 4.72 & 9.00 & 2.23 & 24.71 & -0.76 & -0.15 & 0.863 \\
\hline $\mathrm{pH}$ & 6.0 & 3.9 & 4.85 & 0.58 & 12.03 & -0.46 & 0.49 & 0.453 \\
\hline Organic matter $(\%)$ & 8.16 & 1.99 & 3.48 & 2.05 & 58.80 & 1.61 & 1.68 & 0.000 \\
\hline Estimated $\mathrm{N}$ release $\left(\mathrm{lbs}\right.$ acre ${ }^{-1}$ ) & 116 & 60 & 78.17 & 18.93 & 24.22 & -0.026 & 1.07 & 0.003 \\
\hline$S(p p m)$ & 23 & 4.00 & 10.11 & 5.78 & 57.16 & 0.11 & 1.09 & 0.009 \\
\hline $\mathrm{P}\left(\mathrm{mg} \mathrm{kg}^{-1}\right)$ & 8 & $<1.00$ & - & - & - & - & - & - \\
\hline $\mathrm{Ca}\left(\mathrm{mg} \mathrm{kg}^{-1}\right)$ & 1204 & 280 & 601.67 & 276.92 & 46.03 & -0.29 & 0.91 & 0.033 \\
\hline $\operatorname{Mg}\left(\mathrm{mg} \mathrm{kg}^{-1}\right)$ & 219 & 58 & 109.83 & 47.03 & 42.82 & 0.59 & 1.13 & 0.24 \\
\hline $\mathrm{K}\left(\mathrm{mg} \mathrm{kg}{ }^{-1}\right)$ & 122 & 15 & 59.06 & 28.82 & 48.80 & -0.29 & 0.56 & 0.668 \\
\hline $\mathrm{Na}\left(\mathrm{mg} \mathrm{kg}^{-1}\right)$ & 16 & 9 & 13.17 & 2.46 & 18.65 & -1.13 & -0.30 & 0.05 \\
\hline $\mathrm{Al}\left(\mathrm{mg} \mathrm{kg}^{-1}\right)$ & 1223 & 457 & 756.22 & 200.07 & 26.46 & 0.44 & 0.81 & 0.464 \\
\hline Ca saturation (\%) & 59.37 & 17.48 & 33.32 & 12.01 & 36.05 & -0.08 & 0.79 & 0.205 \\
\hline Mg saturation (\%) & 18.69 & 4.88 & 10.36 & 4.02 & 38.79 & -0.29 & 0.93 & 0.018 \\
\hline $\mathrm{K}$ saturation (\%) & 3.64 & 0.59 & 1.76 & 0.94 & 53.59 & -0.46 & 0.74 & 0.112 \\
\hline $\mathrm{Na}$ saturation (\%) & 1.47 & 0.35 & 0.69 & 0.28 & 40.48 & 2.40 & 1.42 & 0.032 \\
\hline $\mathrm{H}(\%)$ & 66.00 & 15.00 & 46.17 & 14.45 & 31.29 & -0.46 & -0.07 & 0.087 \\
\hline $\mathrm{B}\left(\mathrm{mg} \mathrm{kg}^{-1}\right)$ & 0.33 & $<0.2$ & - & - & - & - & - & - \\
\hline $\mathrm{Fe}\left(\mathrm{mg} \mathrm{kg}^{-1}\right)$ & 197 & 35.00 & 109.94 & 36.89 & 33.55 & 1.14 & 0.29 & 0.876 \\
\hline $\operatorname{Mn}\left(\mathrm{mg} \mathrm{kg}^{-1}\right)$ & 234 & 1.00 & 115.83 & 72.73 & 62.79 & -0.75 & -0.13 & 0.285 \\
\hline $\mathrm{Cu}\left(\mathrm{mg} \mathrm{kg}^{-1}\right)$ & 2.37 & 1.06 & 1.73 & 0.35 & 20.27 & -0.22 & -0.03 & 0.947 \\
\hline $\mathrm{Zn}\left(\mathrm{mg} \mathrm{kg}^{-1}\right)$ & 2.63 & $<0.4$ & - & - & - & - & - & - \\
\hline
\end{tabular}

Min: minimum; Max: maximum; SD: standard deviation; CV: coefficient of variation; values with "<" indicate the limit of quantification.

These values fall under very low $(1.61 \%$ and $4.35 \%)$ and low $(82.26 \%$ and $89.13 \%)$ to moderate $(16.13 \%$ and $6.52 \%)$ range for the Far North and North regions, respectively; low $(33.33 \%)$, moderate $(44.44 \%)$, high $(5.56 \%)$, and very high (16.67\%) for the Centre region; very low $(12.50 \%)$, low $(12.50 \%)$, moderate $(3.13 \%)$, and very high $(71.88 \%)$ for Adamawa, and very low (100\%) for West region (Table 7). ENR ranged from 10 to 59,15 to 57,60 to 116,24 to 128 , and 14 to $36 \mathrm{lbs}$ acre $^{-1}$ in samples in the Far North, North,
Centre, Adamawa, and West regions, respectively (Tables 2-6). These values are calculated estimates of nitrogen that may be released annually through organic matter decomposition, and the rating is similar to that of organic matter [44]. With the exception of most of the examined soils in Adamawa and the Centre regions, the low OM levels in the soil samples explain why ENR was low in these soils. This is attributed to the fact that OM is the main source of nitrogen for crops grown without fertilizer application [45]. 
TABle 5: Summary statistics of soil chemical properties within Centre region $(n=32)$.

\begin{tabular}{|c|c|c|c|c|c|c|c|c|}
\hline Soil nutrient & Max & Min & Mean & $\mathrm{SD}$ & $\mathrm{CV}$ & Kurtosis & Skewness & Shapiro-Wilk ( $P$ value) \\
\hline TEC (100 meq/100 g) & 26.54 & 3.53 & 8.41 & 5.00 & 59.43 & 4.40 & 1.83 & 0.000 \\
\hline $\mathrm{pH}$ & 6.00 & 4.20 & 4.79 & 0.55 & 11.47 & -0.15 & 1.05 & 0.000 \\
\hline Organic matter $(\%)$ & 16.29 & 0.60 & 7.49 & 5.27 & 70.44 & -1.06 & 0.49 & 0.001 \\
\hline Estimated $\mathrm{N}$ release $\left(\mathrm{lbs}\right.$ acre $\mathrm{e}^{-1}$ ) & 128 & 24 & 96.69 & 32.60 & 33.72 & -0.24 & -1.01 & 0.000 \\
\hline$S(p p m)$ & 29 & $<1.00$ & - & - & - & - & - & - \\
\hline $\mathrm{P}\left(\mathrm{mg} \mathrm{kg}^{-1}\right)$ & 24 & $<1$ & - & - & - & - & - & - \\
\hline $\mathrm{Ca}\left(\mathrm{mg} \mathrm{kg}^{-1}\right)$ & 3129 & 135 & 554.94 & 531.31 & 95.74 & 18.45 & 3.93 & 0.000 \\
\hline $\mathrm{Mg}\left(\mathrm{mg} \mathrm{kg}^{-1}\right)$ & 480 & 16.00 & 94.22 & 92.25 & 97.91 & 9.83 & 2.89 & 0.000 \\
\hline $\mathrm{K}\left(\mathrm{mg} \mathrm{kg}^{-1}\right)$ & 543 & 23.00 & 86.59 & 93.68 & 108.18 & 19.03 & 4.09 & 0.000 \\
\hline $\mathrm{Na}\left(\mathrm{mg} \mathrm{kg}^{-1}\right)$ & 20.00 & 8.00 & 13.13 & 3.43 & 26.16 & -0.69 & 0.22 & 0.144 \\
\hline $\mathrm{Al}\left(\mathrm{mg} \mathrm{kg}^{-1}\right)$ & 1486 & 399 & 1066.28 & 312.93 & 29.35 & 016 & -1.09 & 0.000 \\
\hline Ca saturation $(\%)$ & 60.85 & 17.13 & 32.04 & 12.16 & 37.94 & 0.51 & 1.27 & 0.000 \\
\hline Mg saturation (\%) & 16.82 & 2.13 & 8.96 & 3.94 & 43.98 & -0.81 & 0.23 & 0.420 \\
\hline $\mathrm{K}$ saturation $(\%)$ & 7.77 & 0.82 & 2.84 & 1.79 & 63.08 & 0.70 & 1.13 & 0.003 \\
\hline $\mathrm{Na}$ saturation (\%) & 1.50 & 0.33 & 0.81 & 0.31 & 38.69 & -0.74 & 0.40 & 0.953 \\
\hline $\mathrm{H}(\%)$ & 61.00 & 15.00 & 47.53 & 13.97 & 29.38 & 0.35 & -1.26 & 0.000 \\
\hline $\mathrm{B}\left(\mathrm{mg} \mathrm{kg}^{-1}\right)$ & 0.71 & $<0.2$ & - & - & - & - & - & - \\
\hline $\mathrm{Fe}\left(\mathrm{mg} \mathrm{kg}^{-1}\right)$ & 234 & 35.00 & 70.66 & 36.88 & 52.19 & 12.11 & 3.00 & 0.000 \\
\hline $\mathrm{Mn}\left(\mathrm{mg} \mathrm{kg}^{-1}\right)$ & 140 & 2.00 & 36.34 & 38.84 & 106.88 & 1.41 & 1.57 & 0.000 \\
\hline $\mathrm{Cu}\left(\mathrm{mg} \mathrm{kg}^{-1}\right)$ & 2.07 & 0.37 & 1.26 & 0.47 & 37.69 & -0.88 & -0.09 & 0.514 \\
\hline $\mathrm{Zn}\left(\mathrm{mg} \mathrm{kg}^{-1}\right)$ & 1.31 & $<0.4$ & - & - & - & - & - & - \\
\hline
\end{tabular}

Min: minimum; Max: maximum; SD: standard deviation; CV: coefficient of variation; values with "<" indicate the limit of quantification.

TABle 6: Summary statistics of soil chemical properties within West region $(n=5)$.

\begin{tabular}{|c|c|c|c|c|c|c|c|c|}
\hline Soil properties & Max & Min & Mean & $\mathrm{SD}$ & $\mathrm{CV}$ & Kurtosis & Skewness & Shapiro-Wilk ( $P$ value) \\
\hline TEC (100 meq/100 g) & 5.12 & 2.46 & 3.54 & 1.20 & 34.04 & -2.46 & 0.66 & 0.191 \\
\hline $\mathrm{pH}$ & 6.20 & 4.80 & 5.80 & 0.58 & 10.41 & -1.60 & -0.61 & 0.585 \\
\hline Organic matter $(\%)$ & 0.91 & 0.36 & 0.53 & 0.23 & 42.93 & 2.68 & 1.69 & 0.074 \\
\hline Estimated $N$ release (lbs acre ${ }^{-1}$ ) & 36.00 & 14.00 & 20.80 & 9.01 & 43.32 & 2.72 & 1.70 & 0.074 \\
\hline$S(p p m)$ & 7.00 & 5.00 & 6.20 & 0.84 & 13.49 & -0.61 & -0.51 & 0.314 \\
\hline $\mathrm{P}\left(\mathrm{mg} \mathrm{kg}^{-1}\right)$ & 12.00 & 7.00 & 8.8 & 1.92 & 21.86 & 2.61 & 1.52 & 0.223 \\
\hline $\mathrm{Ca}\left(\mathrm{mg} \mathrm{kg}^{-1}\right)$ & 352 & 277 & 315.80 & 27.81 & 8.81 & 0.42 & -0.17 & 0.953 \\
\hline $\mathrm{Mg}\left(\mathrm{mg} \mathrm{kg}^{-1}\right)$ & 56.00 & 48.00 & 50.80 & 3.56 & 7.02 & -1.12 & 0.94 & 0.159 \\
\hline $\mathrm{K}\left(\mathrm{mg} \mathrm{kg}^{-1}\right)$ & 51.00 & 35.00 & 44.20 & 6.87 & 15.54 & -1.52 & -0.24 & 0.419 \\
\hline $\mathrm{Na}\left(\mathrm{mg} \mathrm{kg}^{-1}\right)$ & 20.00 & 14.00 & 17.20 & 2.28 & 13.26 & 0.18 & -0.41 & 0.814 \\
\hline $\mathrm{Al}\left(\mathrm{mg} \mathrm{kg}^{-1}\right)$ & 370 & 260 & 321.40 & 49.85 & 15.51 & -2.73 & -0.47 & 0.278 \\
\hline Ca saturation (\%) & 62.03 & 30.47 & 48.08 & 13.03 & 27.10 & -1.66 & -0.54 & 0.784 \\
\hline Mg saturation (\%) & 16.26 & 8.63 & 12.84 & 3.24 & 25.24 & -2.13 & -0.48 & 0.663 \\
\hline $\mathrm{K}$ saturation $(\%)$ & 4.27 & 2.55 & 3.37 & 0.69 & 20.33 & -1.28 & 0.16 & 0.999 \\
\hline $\mathrm{Na}$ saturation (\%) & 2.83 & 1.53 & 2.25 & 0.54 & 23.83 & -1.53 & -0.36 & 0.925 \\
\hline $\mathrm{H}(\%)$ & 49.00 & 12.00 & 27.20 & 16.07 & 59.07 & -1.96 & 0.65 & 0.467 \\
\hline $\mathrm{B}\left(\mathrm{mg} \mathrm{kg}^{-1}\right)$ & 0.43 & $<0.2$ & - & - & - & - & - & - \\
\hline $\mathrm{Fe}\left(\mathrm{mg} \mathrm{kg}^{-1}\right)$ & 293 & 47.00 & 98.60 & 108.70 & 110.25 & 4.99 & 2.23 & 0.000 \\
\hline $\operatorname{Mn}\left(\mathrm{mg} \mathrm{kg}^{-1}\right)$ & 127 & 29.00 & 85.00 & 41.92 & 49.33 & -2.05 & -0.60 & 0.418 \\
\hline $\mathrm{Cu}\left(\mathrm{mg} \mathrm{kg}^{-1}\right)$ & 1.42 & 0.44 & 0.76 & 0.39 & 50.91 & 3.07 & 1.71 & 0.139 \\
\hline $\mathrm{Zn}\left(\mathrm{mg} \mathrm{kg}^{-1}\right)$ & 0.74 & 0.42 & 0.58 & 0.14 & 23.92 & -2.44 & 0.18 & 0.554 \\
\hline
\end{tabular}

Min: minimum; Max: maximum; SD: standard deviation; CV: coefficient of variation; values with "<" indicate the limit of quantification.

3.2.3. Phosphorus. Available P (Mehlich-3 extractable) varied between 1.0 and $120 \mathrm{mg} \mathrm{kg}^{-1}, 2.0$ and $111 \mathrm{mg} \mathrm{kg}^{-1}$, $<1.0$ and $8.0 \mathrm{mg} \mathrm{kg}^{-1},<1.0$ and $24 \mathrm{mg} \mathrm{kg}^{-1}$, and 7.0 and $12 \mathrm{mg} \mathrm{kg}^{-1}$ in soil samples in the Far North, North, Centre, Adamawa, and West regions, respectively (Tables 2-6). It was found to be very low, low, medium, high, and very high in $53.23 \%, 19.35 \%, 14.51 \%, 4.84 \%$, and $8.06 \%$ of the samples in Far North; very low, low, medium, and very high in 84.78 , $8.70,2.17$, and $4.35 \%$ of samples in North; and very low, low, and medium in $93.75,3.13$, and $3.13 \%$ of samples in Adamawa, respectively. Available phosphorus was 100\% low for samples in Centre and West regions (Table 7). Generally, available $\mathrm{P}$ was deficient in all the soils studied. The small percentages of moderately available $\mathrm{P}$ in samples in Adamawa and the high and very high available $\mathrm{P}$ content in samples in the Far North and North regions might be due to fertilizer residues in the fields as a result of high $\mathrm{P}$ application [46]. This is consistent with other reports stating that soil 
TABLE 7: Critical values of nutrients and soil properties.

\begin{tabular}{|c|c|c|c|c|c|c|}
\hline \multirow{2}{*}{ Soil chemical properties } & \multicolumn{6}{|c|}{ Critical level } \\
\hline & Very low & Low & Medium & High & Very high & Reference \\
\hline Organic matter (\%) & $0-0.3$ & $0.4-1.2$ & $1.3-2.2$ & $2.3-3.2$ & $3.3+$ & {$[44]$} \\
\hline Estimated $N$ release $\left(\mathrm{lbs}\right.$ acre $\left.{ }^{-1}\right)$ & $0-26$ & $27-37$ & $38-47$ & $48-57$ & $58+$ & {$[44]$} \\
\hline Total exchangeable cation $(\mathrm{meq} / 100 \mathrm{~g})$ & $0-4$ & $5-11$ & $12-24$ & $25-40$ & $41+$ & {$[49]$} \\
\hline $\mathrm{P}\left(\mathrm{mm} \mathrm{kg}^{-1}\right)$ & $0-12$ & $13-22$ & $23-35$ & $36-68$ & $69+$ & {$[50]$} \\
\hline $\mathrm{Ca}\left(\mathrm{mm} \mathrm{kg}^{-1}\right)$ & $0-307$ & $308-503$ & $504-700$ & $701-895$ & $896+$ & {$[50]$} \\
\hline $\operatorname{Mg}\left(\mathrm{mm} \mathrm{kg}^{-1}\right)$ & $0-22$ & $23-41$ & $42-71$ & $72-147$ & $148+$ & {$[50]$} \\
\hline $\mathrm{K}\left(\mathrm{mm} \mathrm{kg}^{-1}\right)$ & $0-20$ & $21-40$ & $41-72$ & $73-138$ & $139+$ & [50] \\
\hline $\mathrm{S}(\mathrm{mm} \mathrm{kg})^{-1}$ & $0-10$ & $11-20$ & $21-30$ & $31-40$ & $41+$ & [59] \\
\hline $\mathrm{B}\left(\mathrm{mm} \mathrm{kg}^{-1}\right)$ & - & $<0.70$ & $0.71-1.00$ & $>1.00$ & - & {$[60]$} \\
\hline $\mathrm{Fe}\left(\mathrm{mm} \mathrm{kg}^{-1}\right)$ & - & $<60$ & $60-420$ & $>420$ & - & {$[60]$} \\
\hline $\operatorname{Mn}\left(\mathrm{mm} \mathrm{kg}^{-1}\right)$ & - & $<30$ & $30.1-200$ & $>200$ & - & {$[60]$} \\
\hline $\mathrm{Cu}\left(\mathrm{mm} \mathrm{kg}^{-1}\right)$ & - & $<1.6$ & $1.6-4.5$ & $>4.5$ & - & {$[60]$} \\
\hline $\mathrm{Zn}\left(\mathrm{mm} \mathrm{kg}^{-1}\right)$ & - & $<2.2$ & $2.21-5.0$ & $>5.0$ & - & {$[60]$} \\
\hline
\end{tabular}

available $\mathrm{P}$ variability is related to land-use type and soil management practices $[3,47]$. The results also pointed out the need to consider application of liming materials to bring soil $\mathrm{pH}$ up to ideal levels ( $\mathrm{pH} 6-7$ ) as $\mathrm{P}$ is generally available to crops at this $\mathrm{pH}$ range [47]. Low soil $\mathrm{pH}$ severely limits $\mathrm{P}$ availability to plants, which may cause deficiency symptoms even where high soil test P levels exist [48].

\subsubsection{Total Exchangeable Capacity and Exchangeable Bases.} Total exchangeable capacity (TEC) varies between 3.80 and $35.4,2.08$ and 35.08, 4.72 and 12.77, 3.53 and 26.54, and 2.46 and $5.12 \mathrm{meq} / 100 \mathrm{~g}$ for soil samples in the Far North, North, Centre, Adamawa, and the West regions, respectively (Tables 2-6). According to Landon [49], the soil samples from the Far North $(1.61,38.71,46.77$, and 12.90\%), North (32.61, 56.52, 8.70, and 2.17\%), and Adamawa (28.13, 56.25, 12.5 , and $3.13 \%$ ) were categorized as very low, low, medium, and high in TEC, respectively (Table 7). TEC of soil samples in the Centre region was categorized as very low (5.56\%), low (83.33\%), and medium (11.11\%), whereas TEC level was very low $(80 \%)$ and low $(20 \%)$ for samples in the West region.

The range of exchangeable $\mathrm{K}$ values recorded in soil samples in the Far North, North, Centre, Adamawa, and West regions was 66-600, 30-183, 15-122, 23-543, and $35-51 \mathrm{mg} \mathrm{kg}^{-1}$, respectively (Tables 2-6). Based on rating suggested by Heckman, in 1998 (Table 7), about 3.23\%, $46.77 \%$, and $50 \%$ of sampled soils in Far North were qualified under medium, high, and very high, respectively, in exchangeable K. In the North region, exchangeable $\mathrm{K}$ in the soils was in the range of low (4.35\%), medium (56.52\%), high (34.78\%), and very high (4.35\%), and in the Centre region, it was in the range of very low (5.56\%), low (27.78\%), medium (33.33\%), and high (33.33\%). Additionally, 9.38\%, 56.25\%, $25 \%$, and $9.38 \%$ of the samples in the Adamawa region were qualified as having low, medium, high, and very high exchangeable K level, respectively, while $20 \%$ and $80 \%$ of samples in the West region were qualified medium and high in exchangeable $\mathrm{K}$ level [50].

The range of values for exchangeable $\mathrm{Ca}$ was between 4251 and 291, 4232 and 213, 1204 and 280, 3129 and 135, and
352 and $277 \mathrm{mgkg}^{-1}$ for soil samples in the Far North, North, Centre, Adamawa, and West regions, respectively (Tables 2-6). About (1.61\%, 1.61\%, 3.23\%, 9.68\%, and $83.87 \%),(13.04 \%, 30.43 \%, 17.39 \%, 8.70 \%$, and $30.43 \%)$, (5.56\%, 50\%, 16.67\%, 5.56\%, and $22.22 \%)$, and (13.38\%, $25 \%$, $21.88 \%, 9.38 \%$, and $9.38 \%$ ) of samples in the Far North, North, Centre, and Adamawa regions were found to be very low, low, medium, high, and very high in exchangeable $\mathrm{Ca}$, respectively, whereas $20 \%$ and $80 \%$ of samples in the West region were very low and low in exchangeable $\mathrm{Ca}$, respectively (Table 7). Availability of Ca varies enormously from soil to soil and is highly dependent on a number of other factors. Ca deficiency was found to occur only in soils of low $\mathrm{pH}$ values less than 5.5. Landon [49] also reported deficiencies of $\mathrm{Ca}$ in soils at $\mathrm{pH} \leq 5.5$.

Exchangeable $\mathrm{Mg}$ also varied widely from soil to soil in the study areas. The range of values was between 72 and 1003, 25 and 1140, 58 and 219, 16 and 480, and 48 and $56 \mathrm{mg} \mathrm{kg}^{-1}$ for samples in the Far North, North, Centre, Adamawa, and West regions, respectively (Tables 2-6). Exchangeable $\mathrm{Mg}$ showed high (17.74\%) and very high $(82.26 \%)$ levels for samples in the Far North and low $(8.70 \%)$, medium $(34.78 \%)$, high $(34.78 \%)$, and very high $(21.74 \%)$ for samples in the North region (Table 7). Additionally, about $27.78 \%, 55.56 \%$, and $16.67 \%$ of samples in the Centre region were medium, high, and very high, respectively; about $3.13 \%, 18.75 \%, 31.25 \%, 34.38 \%$, and $12.50 \%$ of soils samples in the Adamawa region were very low, low, medium, high, and very high, respectively, while $100 \%$ of soil samples in the West region was medium. There is usually an inverse and adverse relationship between a very high concentration of one cation in the soil and the availability and uptake of other cations by plant $[33,51]$; that is, if $\mathrm{Ca}$ and/or $\mathrm{Mg}$ dominates the exchange complex over $\mathrm{K}$, it may reduce $\mathrm{K}$ availability and potentially result in $\mathrm{K}$ deficiency $[33,52,53]$. This implies that $\mathrm{K}$ availability does not only solely depend on the $\mathrm{K}$ content of soils but also depends on the relative amounts of other cations ( $\mathrm{Ca}$ and $\mathrm{Mg}$ ). Thus, knowledge on the relative proportion of cations ( $\mathrm{Ca}, \mathrm{Mg}$, and $\mathrm{K}$ ) than single cation evaluation (e.g., K) has been suggested in exploring 


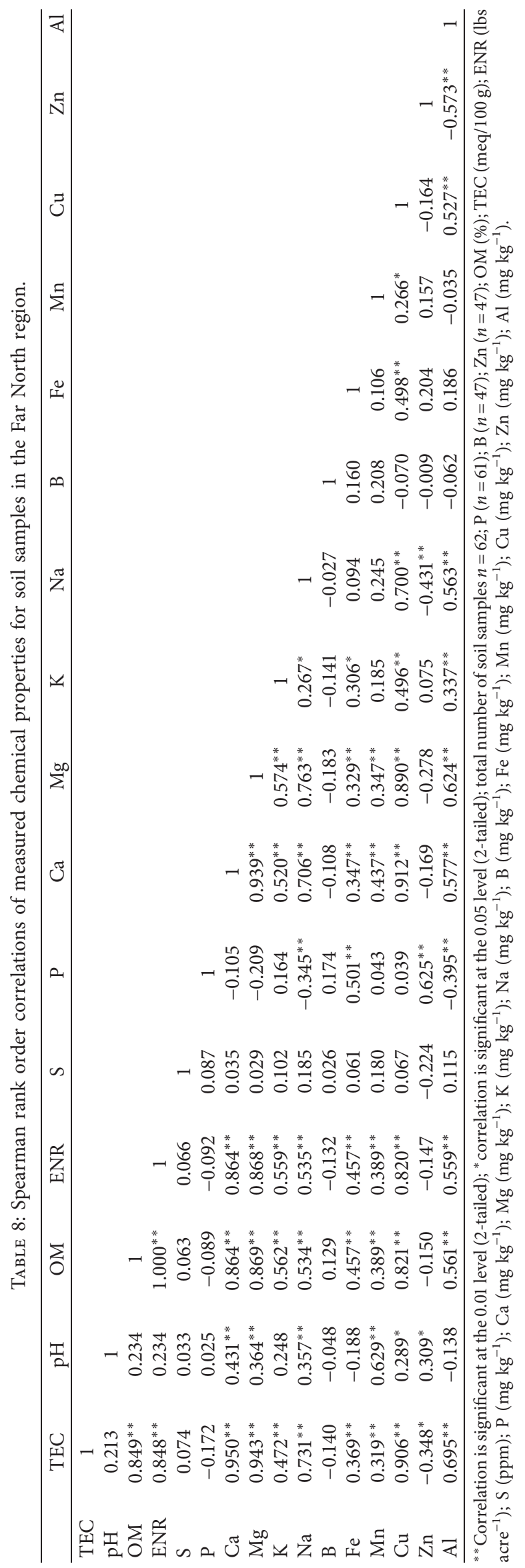




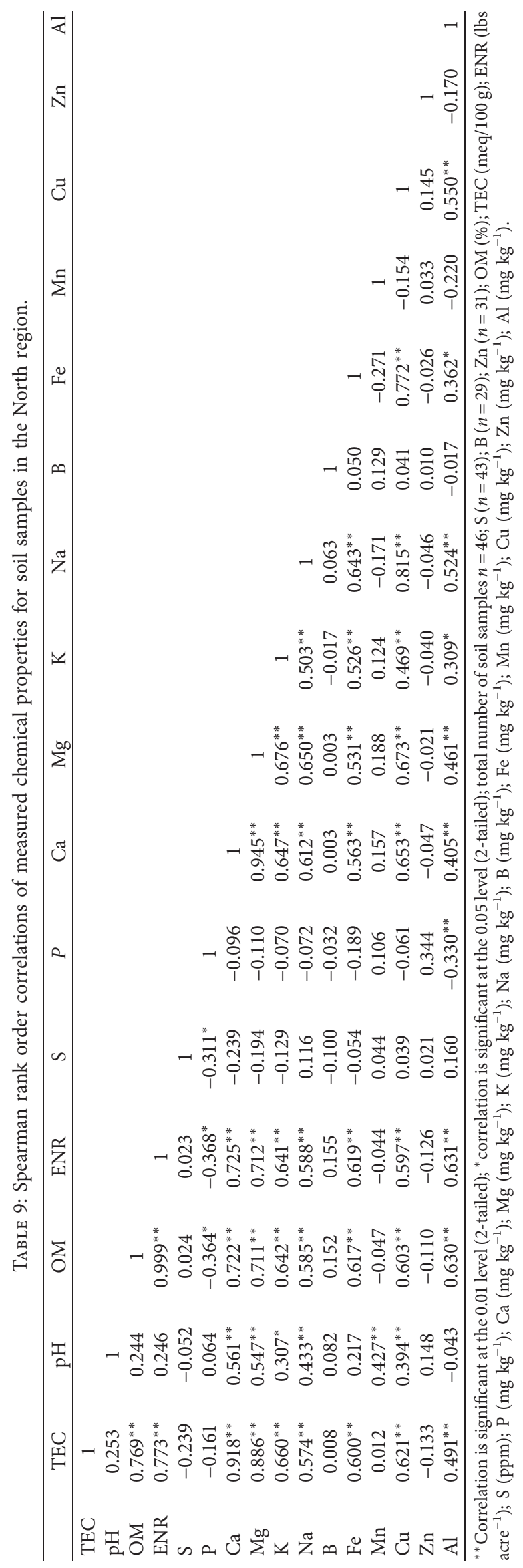




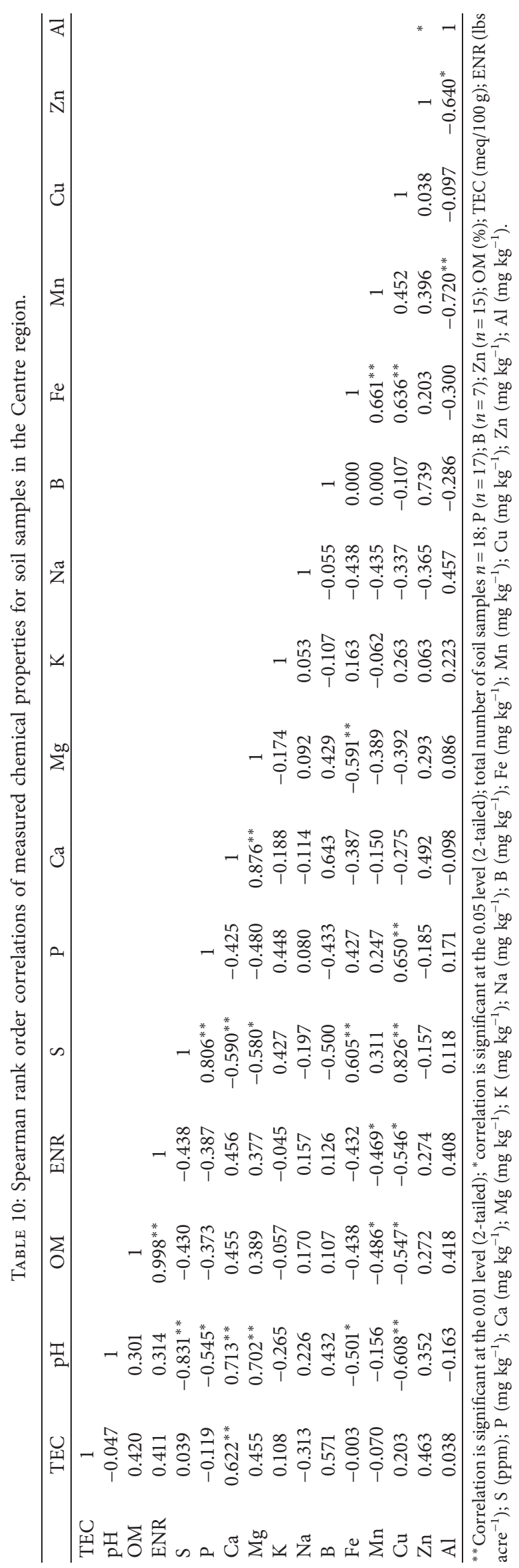




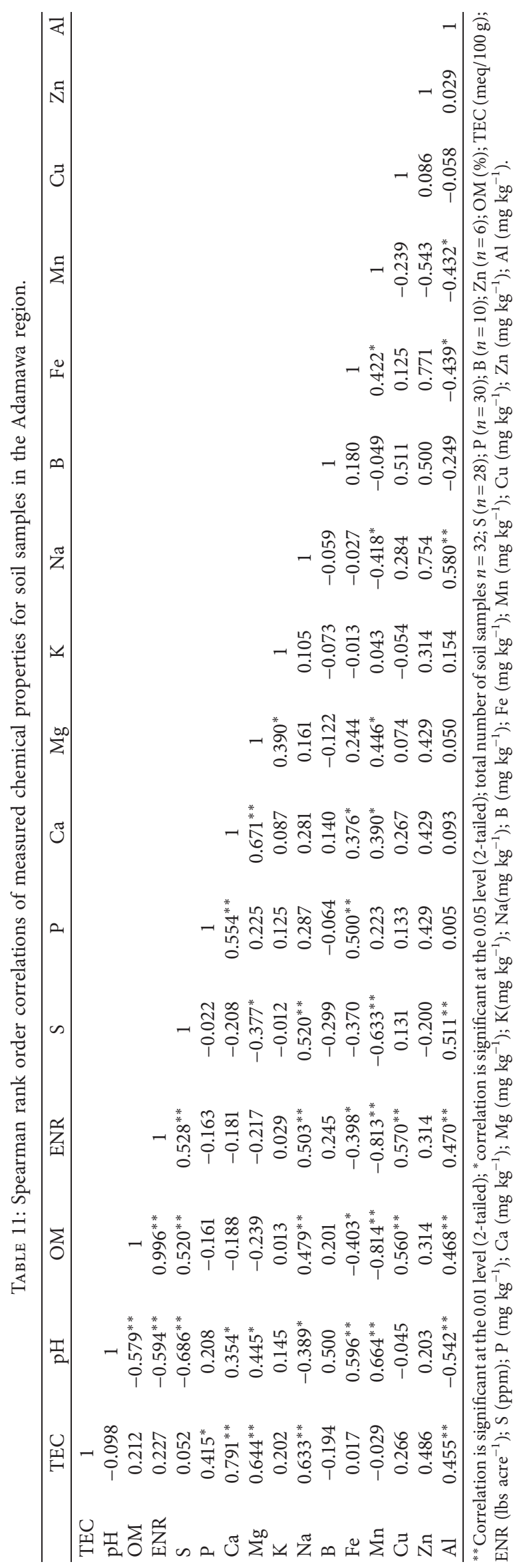


TABLE 12: Spearman rank order correlations of measured chemical properties for soil samples in the West region.

\begin{tabular}{|c|c|c|c|c|c|c|c|c|c|c|c|c|c|c|c|c|}
\hline & TEC & $\mathrm{pH}$ & $\mathrm{OM}$ & ENR & $S$ & $\mathrm{P}$ & $\mathrm{Ca}$ & $\mathrm{Mg}$ & $\mathrm{K}$ & $\mathrm{Na}$ & $\mathrm{B}$ & $\mathrm{Fe}$ & $\mathrm{Mn}$ & $\mathrm{Cu}$ & $\mathrm{Zn}$ & $\mathrm{Al}$ \\
\hline TEC & 1 & & & & & & & & & & & & & & & \\
\hline $\mathrm{pH}$ & $-0.900^{*}$ & 1 & & & & & & & & & & & & & & \\
\hline $\mathrm{OM}$ & 0.700 & -0.600 & 1 & & & & & & & & & & & & & \\
\hline ENR & 0.564 & -0.410 & $0.975^{* *}$ & 1 & & & & & & & & & & & & \\
\hline S & 0.580 & -0.738 & 0.369 & 0.189 & 1 & & & & & & & & & & & \\
\hline $\mathrm{P}$ & 0.051 & -0.205 & -0.616 & -0.763 & 0.406 & 1 & & & & & & & & & & \\
\hline $\mathrm{Ca}$ & 0.500 & -0.200 & 0.600 & 0.667 & -0.369 & -0.616 & 1 & & & & & & & & & \\
\hline $\mathrm{Mg}$ & 0.872 & -0.872 & 0.872 & 0.763 & 0.460 & -0.289 & 0.564 & 1 & & & & & & & & \\
\hline K & 0.872 & $-0.975^{* *}$ & 0.718 & 0.553 & 0.649 & 0.000 & 0.308 & $0.947^{*}$ & 1 & & & & & & & \\
\hline $\mathrm{Na}$ & 0.718 & -0.821 & 0.872 & 0.763 & 0.541 & -0.342 & 0.359 & $0.947^{*}$ & $0.921^{*}$ & 1 & & & & & & \\
\hline B & - & - & - & - & - & - & - & - & - & - & - & & & & & \\
\hline $\mathrm{Fe}$ & -0.100 & 0.200 & 0.100 & 0.205 & -0.791 & -0.564 & 0.700 & 0.154 & -0.051 & 0.051 & - & 1 & & & & \\
\hline $\mathrm{Mn}$ & 0.800 & $0.900^{*}$ & -0.800 & -0.667 & -0.527 & 0.205 & -0.400 & $-0.975^{* *}$ & $-0.975^{* *}$ & $-0.975^{* *}$ & - & -0.100 & 1 & & & \\
\hline $\mathrm{Cu}$ & 0.800 & -0.600 & 0.700 & 0.667 & 0.000 & -0.359 & $0.900^{*}$ & 0.821 & 0.667 & 0.616 & - & 0.500 & -0.700 & 1 & & \\
\hline $\mathrm{Zn}$ & 0.300 & -0.100 & 0.800 & 0.872 & 0.211 & -0.718 & 0.400 & 0.410 & 0.205 & 0.462 & - & -0.100 & -0.300 & 0.300 & 1 & \\
\hline $\mathrm{Al}$ & 0.600 & -0.700 & $0.900^{*}$ & 0.821 & 0.527 & -0.462 & 0.300 & 0.872 & 0.821 & $0.975^{* *}$ & - & 0.000 & $-0.900^{*}$ & 0.500 & 0.600 & 1 \\
\hline
\end{tabular}

${ }^{* *}$ Correlation is significant at the 0.01 level (2-tailed); ${ }^{*}$ correlation is significant at the 0.05 level (2-tailed); total number of soil samples $n=5$ (NB: most of B concentrations were below detection limit); OM (\%); TEC (meq/100 g); ENR (lbs acre $\left.\left.{ }^{-1}\right) ; \mathrm{S}(\mathrm{ppm}) ; \mathrm{P}\left(\mathrm{mg} \mathrm{kg}^{-1}\right) ; \mathrm{Ca}\left(\mathrm{mg} \mathrm{kg}^{-1}\right) ; \mathrm{Mg}^{(\mathrm{mg} \mathrm{kg}}{ }^{-1}\right) ; \mathrm{K}\left(\mathrm{mg} \mathrm{kg}^{-1}\right) ; \mathrm{Na}$ $\left(\mathrm{mg} \mathrm{kg}^{-1}\right) ; \mathrm{B}\left(\mathrm{mg} \mathrm{kg}^{-1}\right) ; \mathrm{Fe}\left(\mathrm{mg} \mathrm{kg}^{-1}\right) ; \mathrm{Mn}\left(\mathrm{mg} \mathrm{kg}^{-1}\right) ; \mathrm{Cu}\left(\mathrm{mg} \mathrm{kg}^{-1}\right) ; \mathrm{Zn}\left(\mathrm{mg} \mathrm{kg}^{-1}\right) ; \mathrm{Al}\left(\mathrm{mg} \mathrm{kg}^{-1}\right)$.

nutrient antagonism and ensuring sufficient supply of each nutrient. Yet, this potential-induced limitation has been overlooked mostly by depending only on soil exchangeable $\mathrm{K}$ values to ascertain soil $\mathrm{K}$ status $[33,52,54]$. Since Mehlich-3 extraction solution was used in this study, a $\mathrm{K}-\mathrm{Mg}$ threshold value of 0.7 described by Loide [55] and temporarily adopted by Laekemariam et al. [33] to demonstrate the potential Mg-induced $\mathrm{K}$ deficiency was used. The results showed that, with the exception of $6.25 \%$ of samples in the Adamawa region (K$\mathrm{Mg}>0.8$ ), the soils in all the experimental sites were prone to $\mathrm{Mg}$-induced $\mathrm{K}$ deficiency (Supplementary material: Tables 1S-5S). Intensive cropping, complete removal of crop residue, wide spread use of fertilizers materials which contain little or no $\mathrm{Mg}$ and $\mathrm{K}$, or nonuse of mineral $\mathrm{Mg}$ and $\mathrm{K}$ fertilizer in soils of the study areas might have been the cause of this imbalance.

Osemwota et al. [56] showed that, under field conditions, exchangeable $\mathrm{Ca}-\mathrm{Mg}$ ratios showed no significant effect on $\mathrm{Mg}$ availability, uptake, and maize grain yield in the $\mathrm{Ca}-\mathrm{Mg}$ ratio between 1 and 8 . Others have argued that if soil calcium and magnesium levels and soil $\mathrm{pH}$ are acceptable, variation in the $\mathrm{Ca}-\mathrm{Mg}$ ratio between 2 and 8 has no influence on crop yield [57]. The $\mathrm{Ca}-\mathrm{Mg}$ ratio revealed that all soil samples from the different AEZs were within this range.

3.2.5. Sulphur. Mehlich-3 extractable $S$ in the study sites ranged from 1.0 to $11,<1.0$ to $7.0,4.0$ to $23,<1.0$ to 29 , and 5.0 to $7.0 \mathrm{mg} \mathrm{kg}^{-1}$ for soils in the Far North, North, Centre, Adamawa, and West regions, respectively (Tables 2-6). The available S contents of samples in the Far North (98.39\%), North (100\%), Centre (66.67\%), Adamawa (78.13\%), and West $(100 \%)$ regions were found to be very low. $1.61 \%$, $22.22 \%$, and $15.63 \%$ were found to be low for samples in the Far North, Centre, and Adamawa regions, whereas 11.11\% and $6.25 \%$ of samples were medium for soils in the Centre and Adamawa regions, respectively [58]. S deficiency has not been reported and is overlooked in the study areas as is not part of the routine soil analysis in Cameroon.

3.2.6. Micronutrients. The Mehlich-3 extractable B ranged from less than 0.20 to $0.73,0.80,0.33,0.71$, and $0.43 \mathrm{mg} \mathrm{kg}^{-1}$ in the surface soils in the Far North, North, Centre, Adamawa, and West regions, respectively (Tables 2-6). The majority of the soil samples in the Far North (98.39\%), North (95.65\%), Centre (100\%), Adamawa (96.88\%), and West (100\%) regions were under low B category (Table 7), whereas the remaining soil sample proportions: $1.61 \%, 4.35 \%$, and $3.13 \%$ were qualified under moderate B level, respectively, for Far North, North, and Adamawa regions. Also, Mehlich3 extractable $\mathrm{Zn}$ ranged from less than 0.40 to $3.46,5.36$, 2.63 , and $1.31 \mathrm{mg} \mathrm{kg}^{-1}$ in the surface soils in Far North, North, Centre, and Adamawa regions, respectively, and from 0.42 to $0.74 \mathrm{mg} \mathrm{kg}^{-1}$ in soil samples in the West region (Tables 2-6). The majority of the soil samples in the Far North (91.49\%), North (93.48\%), Centre (94.44\%), Adamawa (100\%), and West (100\%) regions were also low in $\mathrm{Zn}$ (Table 7). Just like $S$ and $B, Z n$ deficiencies have not been reported and are overlooked in the study areas and not part of the routine soil analysis. Mehlich- 3 extractable Fe ranged from 54 to 177,41 to 297,35 to 197,35 to 234 , and 47 to $293 \mathrm{mg} \mathrm{kg}^{-1}$ for soil samples in the Far North, North, Centre, Adamawa, and West regions, respectively (Tables 2-6). Contrary to low level of Mehlich-3 extractable B and $\mathrm{Zn}$ in majority of the sampled soils, Fe was moderate for most of the soils in the Far North (96.77\%), North (73.91\%), and Centre $(94.44 \%)$, while the other proportions were low. Nonetheless, $53.13 \%$ and $80 \%$ of the soils examined in the Adamawa and West regions were low in $\mathrm{Fe}$, respectively, while the remaining percent is moderate (Table 7). Mehlich- 
3 extractable $\mathrm{Cu}$ ranging from 0.41 to $2.83,0.24$ to $3.01,1.06$ to $2.37,0.37$ to 2.07 , and 0.44 to $1.42 \mathrm{mg} \mathrm{kg}^{-1}$ (Tables 2-6) was low in $74.19 \%, 78.26 \%, 38.89 \%, 75 \%$, and $100 \%$ in soil samples in the Far North, North, Centre, Adamawa, and West regions, respectively, while $25.81 \%, 21.74 \%, 61.11 \%$, and $25 \%$ of soils from the Far North, North, Centre, and Adamawa were moderate (Table 7$)$. Although $\mathrm{Cu}$ level was low in most of the sites $\left(<2 \mathrm{mg} \mathrm{kg}^{-1}\right)$ (Supplementary material: Tables 1S-5S), this value is however recommended for cereal crops [59]. Accordingly, Mehlich-3 extractable Mn was found in the range of 29 to 191,16 to 252,1 to 234,2 to 140 , and 29 to $127 \mathrm{mg} \mathrm{kg}^{-1}$ in soils from the Far North, North, Centre, Adamawa, and West regions, respectively (Tables 2-6). 96.77\%, 91.30\%, 61.11\%, 46.88\%, and $80 \%$ of these values fall under medium range, while $3.23 \%, 4.35 \%$, $16.67 \%, 53.13 \%$, and $20 \%$ were low for the examined sites in the Far North, North, Centre, Adamawa, and West regions, respectively. Bitondo et al. [60] found out that, in an intensively Cultivated Typic Dystrandepts in Mount Bambouto in the West region of Cameroon, 53\% and $8 \%$ of the soils examined were deficient in $\mathrm{Cu}$ and $\mathrm{Zn}$, respectively, while $\mathrm{Fe}$ and $\mathrm{Mn}$ were inadequate supplies.

3.3. Soil Nutrient Adequacy for Maize, Sorghum, and Cassava Production. Maize is cultivated in all the agroecological zones of Cameroon and is regularly consumed by 12 million Cameroonians [61]. Cassava thrives across a wide range of agroecological zones (zones 2 and 5 in this study) with an annual production of 2.3 million tons [62], while sorghum is mostly cultivated in the Sudano-Sahelian zone (Far North and North regions) with an annual production of 100 thousand tons. In 2015, the government of Cameroon and her partners launched the Agriculture Investment and Market Development Project (aka PIDMA) aimed at boosting production of maize, cassava, and sorghum for local agroindustries. However, productions of these crops have remained low due to poor soil fertility and high fertilizer cost among other factors [63].

Despite the rating of plant nutrients in soil, various crops differ in their nutrient requirements. Each crop has its own specific macro- and micronutrients requirements for optimum growth and yield. In addition, the nutrient requirements and final nutrient contents of a particular crop can also vary depending on the cultivar. Nutrient requirements for a specific type of crop would be useful as a soil interpretation guide for fertilizer and amendment suggestions according to the growing area [64].

Critical level of a soil nutrient including other important soil chemical properties like $\mathrm{pH}$ is defined as the soil test value below which an increase in crop yield can be obtained with addition of the nutrient in question [65]. The nutrient is therefore considered adequate and will probably not limit crop growth. The Mehlich-3 soil test method has been considerably studied with different crops and calibrated with other soil test methods so that there is substantial information in literature [66].

Based on a literature review reported by Wendt [65], relating to the Mehlich-3 extractant, the following critical level of nutrients (Ca, $42 \mathrm{mg} \mathrm{kg}^{-1} ; \mathrm{Mg}, 64 \mathrm{mg} \mathrm{kg}^{-1} ; \mathrm{Mg} / \mathrm{Ca},>$ 0.067; K, $59 \mathrm{mg} \mathrm{kg}^{-1}$; $\mathrm{P}, 17 \mathrm{mg} \mathrm{kg}^{-1} ; \mathrm{Zn}, 0.9 \mathrm{mg} \mathrm{kg}^{-1}$; and $\mathrm{Cu}$, $0.4 \mathrm{mg} \mathrm{kg}^{-1}$ ) were adapted to interpret soil test values for maize production. These values were obtained by dividing the values reported by Wendt [65] with their mean soil density $\left(1.18 \mathrm{~g} \mathrm{~cm}^{-3}\right)$ to convert from $\mathrm{mg} \mathrm{dm}^{-3}$ to $\mathrm{mg} \mathrm{kg}^{-1}$. The $\mathrm{pH}$ range of $5.2-8.5$ has been found to be adequate for maize production [67]. In this regard, about $96.77 \%, 86.96 \%$, $22.22 \%, 21.88 \%$, and $80 \%$ of soils in the Far North, North, Centre, Adamawa, and West regions were in the desirable range, respectively. However, the optimum $\mathrm{pH}$ range for maize is 5.8-7.8. The majority of soils in the Centre and Adamawa regions needs lime materials to raise soil $\mathrm{pH}$ to the adequate range for maize cultivation. The observed $\mathrm{pH}$ values in these two regions might be associated with removal of bases through crop harvest and leaching of base cations [53]. All of the fields sampled in the Far North had adequate soil $\mathrm{Ca}, \mathrm{Mg}, \mathrm{Mg} / \mathrm{Ca}$ ratio, $\mathrm{K}$, and $\mathrm{Cu}$, while only $38.71 \%$ and $27.42 \%$ had sufficient $\mathrm{P}$ and $\mathrm{Zn}$ levels, respectively. All of the crop fields in the North region had sufficient Ca level and $\mathrm{Mg} / \mathrm{Ca}$ ratio. $63.04 \%, 60.87 \%$, and $89.13 \%$ had sufficient $\mathrm{Mg}$, $\mathrm{K}$, and $\mathrm{Cu}$ levels, respectively, while the majority of the soils were deficient in $\mathrm{P}(89.13 \%)$ and $\mathrm{Zn}(80.43 \%)$ for maize production. Moving to the Centre region, none of the field was deficient in $\mathrm{Ca}, \mathrm{Mg} / \mathrm{Ca}$ ratio, and $\mathrm{Cu}$, and only $5.56 \%$ of the fields had insufficient $\mathrm{Mg}$ level for maize production. Contrary to the above nutrients, all of the sampled fields were severely deficient in P (100\%), while $55.56 \%$ of the soils had $\mathrm{K}$ and $\mathrm{Zn}$ contents below the critical level for maize. The crop fields in the Adamawa regions had adequate $\mathrm{Ca}(100 \%)$, $\mathrm{Mg} / \mathrm{Ca}$ ratio $(100 \%)$, and $\mathrm{Cu}(96.88 \%)$. Almost half the sampled fields were deficient in $\mathrm{Mg}$ (43.75\%) and $\mathrm{K}$ (40.62\%), while almost all the fields were low in $\mathrm{Zn}(90.62 \%)$ and severely low in P (96.87\%). All the crop fields in the West region had sufficient $\mathrm{Ca}, \mathrm{Mg} / \mathrm{Ca}$ ratio, and $\mathrm{Cu}$ but deficient in $\mathrm{Mg}, \mathrm{K}, \mathrm{P}$, and $\mathrm{Zn}$ for the production of maize.

Howeler [68-70] reported approximate soil chemical characteristics according to the nutritional requirements for cassava. Ammonium acetate was used as extractant for soil exchangeable $\mathrm{K}, \mathrm{Ca}$, and $\mathrm{Mg}$ extraction. However, Wendt [65] showed that, on average, the Mehlich-3 method extracted almost identical amount of exchangeable $\mathrm{Ca}$ and $\mathrm{Mg}$ and slightly more $\mathrm{K}$ as the ammonium acetate method. These values were therefore adapted to interpret soil nutrients in this study. Mylavarapu et al. [71] evaluated Mehlich-1 and Mehlich-3 extraction procedures for plant nutrients in acid and near neutral soil pH range of Florida soils and showed that micronutrients had approximately equivalent extractability. The critical values of Howeler [70] for micronutrients were also adapted in this study, while the critical level of $\mathrm{S}$ was that reported for $\mathrm{S}$ critical level for cassava in Ethiopia [53]. P was analyzed by the Bray II method. Thus, the following range/level was rated as suitable for cassava production: $\mathrm{P},>4 \mathrm{mg} \mathrm{kg}^{-1} ; \mathrm{K}, 59-98 \mathrm{mg} \mathrm{kg}^{-1}$; Ca, 200-1000 mg kg-1 $\mathrm{Mg}, 48-120 \mathrm{mg} \mathrm{kg}^{-1} ; \mathrm{S}, 20 \mathrm{mg} \mathrm{kg}^{-1} ; \mathrm{Zn}$, $1.0-5.0 \mathrm{mg} \mathrm{kg}^{-1}$; $\mathrm{Cu}, 0.3-1.0 \mathrm{mg} \mathrm{kg}^{-1}$; Fe, $10-100 \mathrm{mg} \mathrm{kg}^{-1}$; and $\mathrm{Mn}, 10-100 \mathrm{mg} \mathrm{kg}^{-1}$. Cassava tolerates wider soil $\mathrm{pH}$ range (4.5-8.2) with optimum $\mathrm{pH}$ ranging from 5.2 to 7.0 [66]. Majority of the $\mathrm{pH}$ values of soil samples from the 
Centre (72.22\%) and Adamawa (62.50\%) regions (AEZs 2 and 5) within the adequate range (4.5-8.2) for cassava production. However, only 22.22 and $21.88 \%$ of the examined soil samples in the Centre and Adamawa regions were in the best $\mathrm{pH}$ range (5.2 to 7.0) for growing cassava, respectively. All the fields in the Centre region had adequate $\mathrm{Ca}, \mathrm{Mg}, \mathrm{Cu}$, and $\mathrm{Fe}$, while $83.33 \%$ had $\mathrm{Mn}$ above the suitable range for cassava. However, $\mathrm{P}(100 \%), \mathrm{K}$ (55.56\%), S (88.89\%), and $\mathrm{Zn}(66.67 \%)$ were below the critical level for cassava production. In the Adamawa region, $\mathrm{Cu}$ and $\mathrm{Fe}$ were adequate in all of the soil samples. $\mathrm{Ca}, \mathrm{Mg}$, and $\mathrm{Mn}$ were sufficient in most of the study area, as $93.75 \%, 68.75 \%$, and $75.00 \%$ of the soils had $\mathrm{Ca}, \mathrm{Mg}$, and $\mathrm{Mn}$ above their critical values or sufficient ranges, respectively, for cassava. Also, $\mathrm{K}$ sufficiency in the soils was just above average (56.25\%), while majority of the soils were deficient in P (90.62\%), S (93.75\%), and $\mathrm{Zn} \mathrm{(93.75 \% )} \mathrm{for} \mathrm{cassava} \mathrm{production.} \mathrm{Laekemariam} \mathrm{[53]}$ found out that smallholder cassava farms in Southern Ethiopia were deficient amongst other soil nutrients in $\mathrm{P}, \mathrm{S}$, and $\mathrm{Zn}$.

Kahsay et al. [72] and Amed and Jeb [73] reported the soil chemical properties suitability criteria for grain sorghum production where exchangeable cations $(\mathrm{K}, \mathrm{Ca}$, and $\mathrm{Mg}$ ) were extracted by the ammonium acetate method such that $59-156 \mathrm{mg} \mathrm{kg}^{-1}$ was used as suitable range for $\mathrm{K}$; $800-2000 \mathrm{mg} \mathrm{kg}^{-1}$ for $\mathrm{Ca}$, and $60-600 \mathrm{mg} \mathrm{kg}^{-1}$ for $\mathrm{Mg}$. Soil critical available P determined by Mehlich-3 was $20 \mathrm{mg} \mathrm{kg}^{-1}$ [74]. The critical limit for $\mathrm{Zn}, \mathrm{Cu}$, and Fe in sorghum soils is $>0.3$ or $0.8 \mathrm{mg}$ DTPA-Zn kg${ }^{-1}$ (for soils with $\mathrm{pH}<7$ and $\mathrm{pH}$ $>7$, respectively), $>0.2 \mathrm{mg}$ DTPA-Cu kg${ }^{-1}$, and $>4.00 \mathrm{mg}$ DTPA-Fe kg ${ }^{-1}$, respectively [75]. According to relationship between Mehlich-3 (M3) extractable nutrients and standard diethylenetriaminepentaacetic acid (DTPA) soil tests of University of Missouri (M3-Zn=1.5 DTPA-Zn+0.7, M3$\mathrm{Cu}=0.88$ DTPA-Cu+0.45, and $\mathrm{M} 3-\mathrm{Fe}=2.3$ DTPA$\mathrm{Fe}+97.2$ ), the Mehlich-3 critical values $>1.15$ or $1.90 \mathrm{mg}$ $\mathrm{Zn} \mathrm{kg}^{-1}$ (for soils with $\mathrm{pH}<7$ and $\mathrm{pH}>7$, respectively); $0.63 \mathrm{mg} \mathrm{Cu} \mathrm{kg}{ }^{-1}$ and $>107.60 \mathrm{mg} \mathrm{Fe} \mathrm{kg}^{-1}$ were therefore calculated [76]. Just like maize, the adequate $\mathrm{pH}$ range for sorghum is $5.2-8.5$ [67]. $93.55 \%$ and $82.61 \%$ of the examined soil samples in the Far North and North regions were in the adequate $\mathrm{pH}$ range and had $83.87 \%$ and $67.39 \%$ within the optimum range (5.5-8.2) for sorghum production, respectively. All soil samples in the Far North region had $\mathrm{K}$ and $\mathrm{Mg}$ above the critical value, and most of the soils $\mathrm{Ca}(90.32 \%)$ and $\mathrm{Cu}(91.94 \%)$ were also above the critical value for sorghum production. Nonetheless, 67.74\%, 79.03\%, and $64.52 \%$ of soil samples were deficient in $\mathrm{P}, \mathrm{Zn}$, and $\mathrm{Fe}$, respectively, for sorghum production. For the North region, majority of the soils were sufficient in $\mathrm{K}(60.87 \%), \mathrm{Mg}$ (69.57\%), and $\mathrm{Cu}(63.04 \%)$ while deficient in $\mathrm{P}(93.48 \%), \mathrm{Ca}$ (65.22\%), Zn (89.13\%), and Fe (60.87\%) (all percentages were calculated from Tables $1 \mathrm{~S}-5 \mathrm{~S}$ of the supplementary material).

Generally, the soils in all the AEZs were consistently low in $\mathrm{P}, \mathrm{S}, \mathrm{B}$, and $\mathrm{Zn}$ for maize, sorghum, and cassava production systems. In addition, $\mathrm{P}$ and $\mathrm{Zn}$ are mutually antagonistic in certain circumstances and can cause yield reductions in many crops due to either $\mathrm{P}$ or $\mathrm{Zn}$ deficiency. In most cases, the $\mathrm{P}$-induced $\mathrm{Zn}$ deficiency is due to application of $\mathrm{P}$ fertilizer at high dose to the soils that are low or marginal in available $\mathrm{Zn}$ [77].

3.4. Comparison of Some Soil Chemical Properties. Kruskal-Wallis and Mann-Whitney $U$ tests were conducted to compare the variation and median of soil properties between regions in the selected agroecological zones. Kruskal-Wallis test revealed that most of the analyzed soil parameters significantly differed between the study areas $(P<0.005)$. Mann-Whitney $U$ test showed significant variation $(P<0.005)$ in most of the soil properties across the regions (Figure 2 ). The variation in soil properties across the regions might be due to differences in altitude, precipitation, properties of the dominant soils, and land use [28]. The exchangeable bases ( $\mathrm{Ca}, \mathrm{Mg}, \mathrm{K}$, and $\mathrm{Na}$ ), $\mathrm{pH}$, and TEC were significantly higher for the Far North region as compared to the other regions. This could be due to the presence of high $2: 1$ smectite clay content of the studied Vertisols in this region $[28,29]$. The median values of $\mathrm{H}$ and $\mathrm{Al}$ were significantly higher for soils in Adamawa and the Centre regions as compared to Far North, North, and West regions (Figure 2). The $\mathrm{pH}$ is a measure of $\mathrm{H}^{+}$concentration in soils; the more acidic the soil, the lesser the bases $(\mathrm{Ca}, \mathrm{Mg}, \mathrm{K}$, and $\mathrm{Na}$ ) [8]. It has been suggested that the proportions of the basic cations of the effective cation exchange capacity are more relevant to plant performance than the actual levels in soil $[52,78]$.

3.5. Correlation Relationships. The results of Spearman's correlation analyses carried out to determine relationships between soil chemical properties in the sampling areas are shown in Tables 8-12. Most of the soil chemical properties of samples in the Far North, North, and Adamawa regions were significantly correlated with each other (Tables 8, 9, and 11) as compared to samples in Centre and West regions (Tables 10 and 12). For example, TEC, Ca, Mg, ENR, OM, and $\mathrm{Cu}$ had very strong positive significant correlations $(0.80 \leq r \leq 1.0)$ in soil samples in the Far North region (Table 8$)$ and strong $(6.0 \leq r \leq 7.9)$ to very strong significant positive correlation for samples in the North region (Table 9). These correlations show the role that OM plays in retention of these base cations and in CEC for soils in these regions. Soil OM did not correlate with TEC for soils in Centre, Adamawa, and West regions. OM is often considered as the most important soil property due to its essential effect on other soil properties, especially CEC, sum of base cations, and nutrient content [79]. A strong positive correlation was also observed between TEC and (Ca and $\mathrm{Mg}$ ) for samples in the Adamawa region (Table 11). Other noticeable correlation is the moderate negative correlations between $\mathrm{pH}$ and $\mathrm{Al}$ for soils in the Adamawa region which might be as a result of the extreme to very strong acid $\mathrm{pH}$ range of soils in these areas. Hamilton et al. [80] found negative correlation between soil $\mathrm{pH}$ and $\mathrm{Al}$ saturation on tropical acidic soils in Brazil. Apart from the dependence of $\mathrm{Al}$ on $\mathrm{pH}$, other authors have obtained negative correlation between $\mathrm{pH}$ and $\mathrm{Mn}[81,82]$. Contrary to the findings above, 


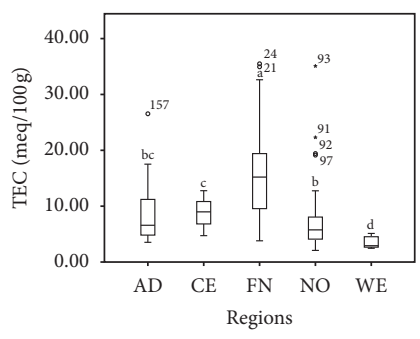

(a)

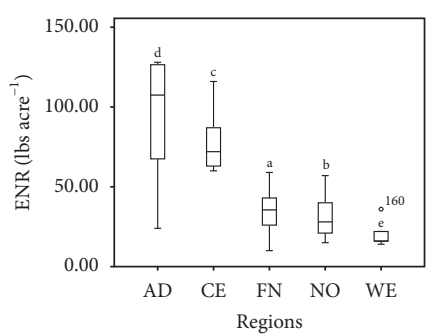

(d)

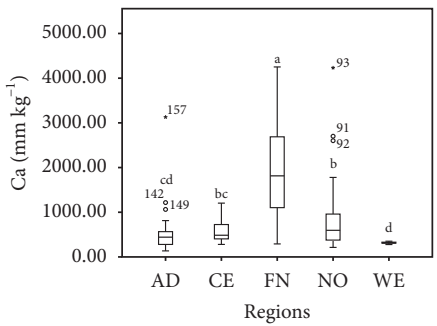

(g)

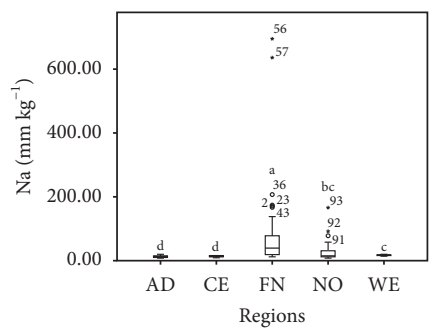

(j)

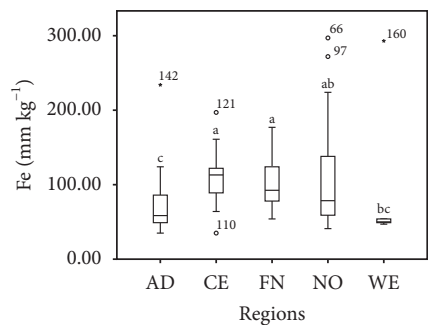

(m)

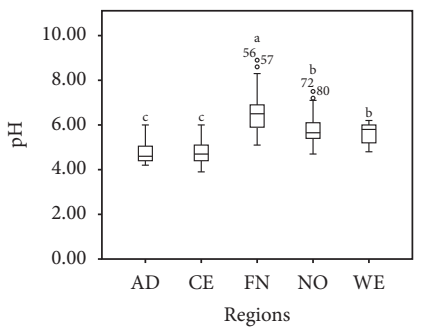

(b)

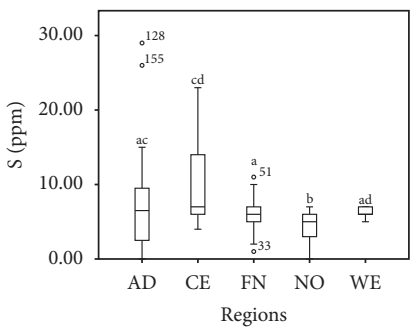

(e)

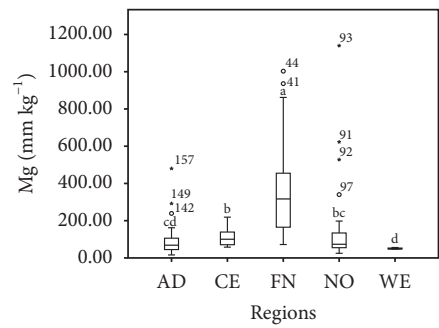

(h)

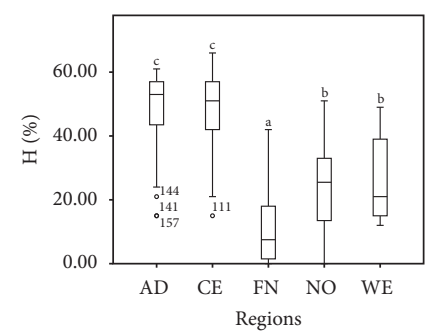

(k)

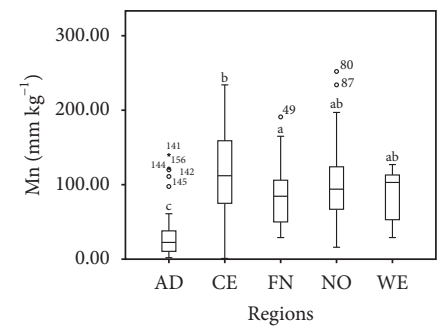

(n)

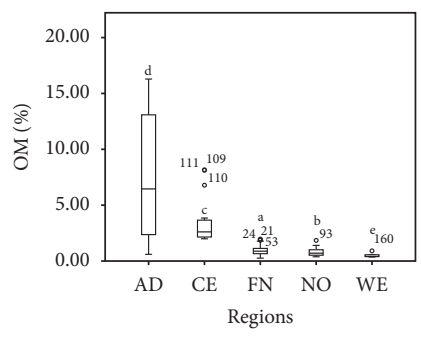

(c)

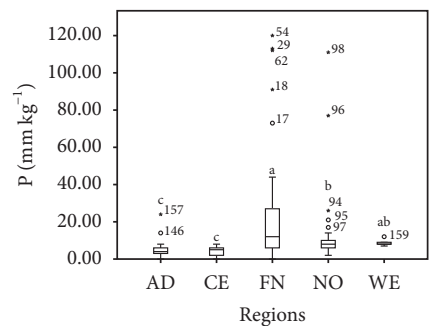

(f)

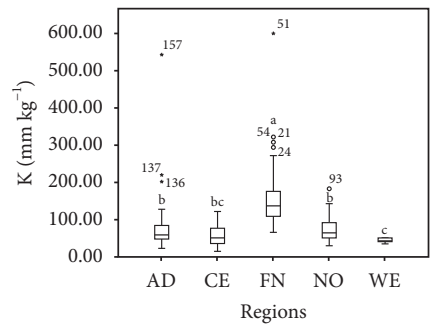

(i)

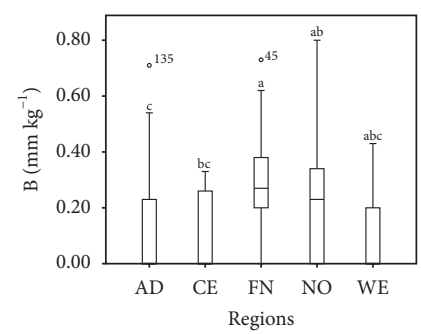

(l)

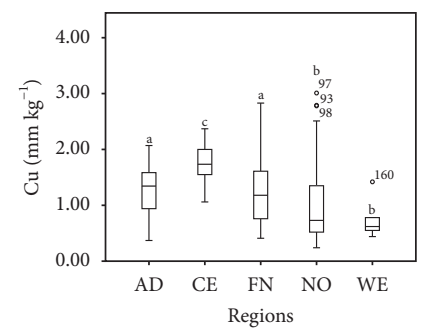

(o)

Figure 2: Continued. 


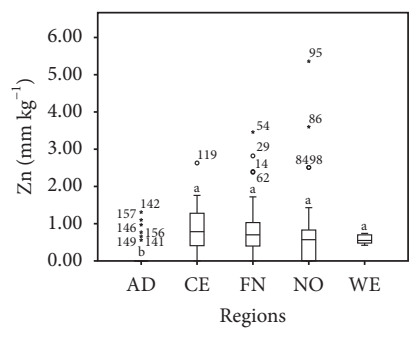

$(\mathrm{p})$

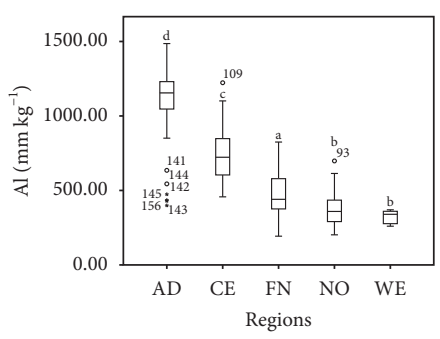

(q)

FIgURE 2: Box plots comparing soil chemical properties in 5 regions. Kruskal-Wallis and Mann-Whitney $U$ tests were applied. Groups with no significant difference are marked by the same letter. AD, Adamawa region; CE, Centre region; FN, Far North region; NO, North region; WE, West region. (a) TEC (meq/100 g); (b) pH; (c) OM (\%); (d) ENR (lbs acre $\left.{ }^{-1}\right)$; (e) S (mm kg $\left.{ }^{-1}\right) ;(f) ~ P\left(\mathrm{~mm} \mathrm{~kg}^{-1}\right)$; (g) Ca (mm kg $\left.{ }^{-1}\right)$; (h) $\mathrm{Mg}\left(\mathrm{mm} \mathrm{kg}^{-1}\right)$; (i) $\mathrm{K}\left(\mathrm{mm} \mathrm{kg}^{-1}\right) ;(\mathrm{j}) \mathrm{Na}\left(\mathrm{mm} \mathrm{kg}^{-1}\right) ;(\mathrm{k}) \mathrm{H}(\%) ;(\mathrm{l}) \mathrm{B}\left(\mathrm{mm} \mathrm{kg}^{-1}\right) ;(\mathrm{m}) \mathrm{Fe}\left(\mathrm{mm} \mathrm{kg}^{-1}\right) ;$ (n) $\mathrm{Mn}\left(\mathrm{mm} \mathrm{kg}^{-1}\right)$; (o) $\mathrm{Cu}\left(\mathrm{mm} \mathrm{kg}^{-1}\right) ;(\mathrm{p})$ $\mathrm{Zn}\left(\mathrm{mm} \mathrm{kg}^{-1}\right)$; (q) $\mathrm{Al}\left(\mathrm{mm} \mathrm{kg}^{-1}\right)$.

a significant positive correlation between $\mathrm{pH}$ and $\mathrm{Mn}$ was obtained for soils in Far North, North, Adamawa, and West regions (Tables $8,9,11$, and 12 ).

3.6. Soil Fertility Management Implications of the Soil Properties. Low soil available P, S, B, and Zn were identified as major limiting factors in all the study areas. In addition, most of the soils were prone to $\mathrm{Mg}$-induced $\mathrm{K}$ deficiency, and soil pH values in some areas were strongly acidic. Therefore, soil management interventions such as incorporation of organic residues like farmyard manure and plant residues and lime (in acid soils) are recommended for maize in all the AEZs, cassava in the Centre and Adamawa regions, and sorghum in the North and Far North regions. For sustainable crop production, there is also need for guided inorganic fertilizers with S, B, and $\mathrm{Zn}$ as an integral part of recommended blended or compound (NPK) fertilizers.

\section{Conclusion}

This study revealed considerable soil nutrients variability within regions and across different AEZs of Cameroon. The soils in all the regions were consistently deficient in multiple soil nutrients ( $\mathrm{P}, \mathrm{S}, \mathrm{B}$, and $\mathrm{Zn}$ ) and might be inadequate to supply cultivated maize, sorghum, and cassava with the nutrients needed to achieve optimal growth. Most of the soil samples were acidic with the Centre and Adamawa regions having extremely to very strongly acidic soils. These results suggested that management of soil nutrients and $\mathrm{pH}$ should be based on cropping system, and other land-use and site-specific information for appropriate resource management and restoration of soil properties over these heterogeneous landscapes. Thus, it is recommended that analysis of sulphur and micronutrients is included in local routine soil analysis and that the results of the soil tests are calibrated against crop responses from applications of plant nutrients so as to establish fertilizer recommendations for the different farming systems which will favour buildup of soil organic matter. The study however has been limited by a small number of soil samples from different regions, and therefore, a large number of samples are required for future work.

\section{Data Availability}

The data used to support the findings of this study are available from the corresponding author upon request.

\section{Disclosure}

The authors received no specific funding for this work.

\section{Conflicts of Interest}

The authors declare that they have no conflicts of interest.

\section{Acknowledgments}

This work was carried out with financial support from PIDMA. The authors are grateful to Marcien Kuété and Kamdem Gabriel for the topographic map of Cameroon carrying the field data. The authors are also thankful to the Brookside Laboratories INC, New Bremen, USA, for carrying out the soil chemical analyses.

\section{Supplementary Materials}

Table 1S: soil properties and GPS points of soil samples in the Far North region. Table 2S: soil properties and GPS points of soil samples in the North region. Table 3S: soil properties and GPS points of soil samples in the Centre region. Table $4 \mathrm{~S}$ : soil properties and GPS points of soil samples in the Adamawa region. Table 5S: soil properties and GPS points of soil samples in the West region. (Supplementary Materials)

\section{References}

[1] L. T. Nanganoa, J. N. Okolle, V. Missi, J. R. Tueche, L. D. Levai, and J. N. Njukeng, "Impact of different land-use systems on soil physicochemical properties and macrofauna abundance in the humid tropics of Cameroon," Applied and 
Environmental Soil Science, vol. 2019, p. 9, Article ID 5701278, 2019.

[2] S. Ayoubi, F. Khormali, K. L. Sahrawat, and A. C. Rodrigues de Lima, "Assessing impacts of land use change on soil quality indicators in a loessial soil in Golestan province, Iran," Journal of Agricultural Science and Technology, vol. 13, pp. 727-742, 2011.

[3] G. B. Tesfahunegn and T. A. Gebru, "Variation in soil properties under different cropping and other land-use systems in Dura catchment, Northern Ethiopia," PLoS One, vol. 15, no. 2, Article ID e0222476, 2020.

[4] A. F. Ngome, M. Becker, K. M. Mtei, and F. Mussgnug, "Fertility management for maize cultivation in some soils of Western Kenya," Soil and Tillage Research, vol. 117, pp. 69-75, 2011.

[5] A. S. Tening, J. A. I. Omueti, G. Tarawali, and M. A. Mohamed-Saleem, "Potassium status of some selected soils under different land-use systems in the sub-humid zone of Nigeria," Communication in Soil Science and Plant Analysis, vol. 26, no. 5-6, 1995.

[6] J. K. Ladha, H. Pathak, A. Tirol-Padre, and D. Dawe, "Productivity trends in intensive rice-wheat cropping systems in Asia," in Improving the Productivity and Sustainability of RiceWheat Systems, Issues and Impacts, pp. 45-76, ASA Special Publications, ASA, CSSA, SSSA, Madison, WI, USA, 2003.

[7] A. Seth, D. Sarkar, R. E. Masto et al., "Critical limits of Mehlich 3 extractable phosphorous, potassium, sulfur, boron and zinc in soils for nutrition, of rice (Oryza sativa L.)," Journal of Soil Science and Plant Nutrition, vol. 18, no. 2, pp. 512-523, 2018.

[8] C. Nguemezi, P. Tematio, M. Yemefack, D. Tsozue, and T. B. F. Silatsa, "Soil quality and soil fertility status in major soil groups at the Tombel area, South-West Cameroon," Heliyon, vol. 6, no. 2, Article ID e03432, 2020.

[9] Z. P. Stewart, G. M. Pierzynski, B. J. Middendorf, and P. V. V. Prasad, "Approaches to improve soil fertility in subSaharan Africa," Journal of Experimental Botany, vol. 71, no. 2, pp. 632-641, 2020.

[10] B. Haileselassie, T.-J. Stomph, and E. Hoffland, "Teff (Eragrostis tef) production constraints on Vertisols in Ethiopia: farmer' perceptions and evaluation of low soil zinc as yieldlimiting factor," Soil Science and Plant Nutrition, vol. 57, no. 4, pp. 587-596, 2011.

[11] S. Pandey, N. P. Bhatta, P. Paudel et al., Improving Fertilizer Recommendations for Nepalese Farmers with the Help of SoilTesting Mobile Van, Agronomy \& Horticulture-Faculty Publications, 2018, http://digitalcommons.unl.edu/ agronomyfacpub/1180.

[12] A. F. Ngome, M. Becker, M. K. Mtei, and F. Mussgnug, "Maize productivity and nutrient use efficiency in Western Kenya as affected by soil type and crop management," International Journal of Plant Production, vol. 7, pp. 517-536, 2013.

[13] M. S. Zia, F. Hussain, M. Aslam, M. E. Akhtar, and A. Hamid, "Basis for formulation of fertilizer recommendations for crop production," International Journal of Agriculture and Biology, vol. 5, no. 3, pp. 392-396, 2003.

[14] D. Panday, B. Maharjan, D. Chalise, R. K. Shrestha, and B. Twanabasu, "Digital soil mapping in the Bara district of Nepal using kriging tool in ArcGIS," PLoS One, vol. 13, no. 10, Article ID e0206350, 2018.

[15] J. Matula, "A relationship between multi-nutrient soil tests (Mehlich 3, ammonium acetate, and water extraction) and bioavailability of nutrients from soils for barley," Plant Soil and Environment, vol. 55, no. 4, pp. 173-180, 2009.
[16] D. Tsozué, J. P. Nghonda, P. Tematio, and S. D. Basga, "Changes in soil properties and soil organic carbon stocks along an elevation gradient at Mount Bambouto, Central Africa," Catena, vol. 175, pp. 251-262, 2019.

[17] D. Tsozue, P. Tematio, and P. A. Tamfuh, "Relationship between soil characteristics and fertility implications in two typical Dystrandept soils of the Cameroon western highland," International Journal of Soil Science, vol. 11, no. 2, pp. 36-48, 2016.

[18] M. Ngo-Mbogba, M. Yemefack, and B. Nyeck, “Assessing soil quality under different land cover types within shifting agriculture in South Cameroon," Soil and Tillage Research, vol. 150, pp. 124-131, 2015.

[19] D. Tsozué, P. Tamfuh, and S. Bonguen, "Morphology, physicochemical characteristics and land suitability in the western highlands of Cameroon," International Journal of Plant \& Soil Science, vol. 7, no. 1, pp. 29-44, 2015.

[20] E. Temgoua, J. Djoukouo, J. D. H. Likeng, and P. Tematio, "Structural stability of andisols and andic Ferralsols from Mount Bambouto, west Cameroon highlands," Cameroon Journal of Experimental Biology, vol. 10, no. 1, pp. 26-34, 2014.

[21] P. Tematio, E. I. Tsafack, and L. Kengni, "Effects of tillage, fallow and burning on selected properties and fertility status of Andosols in the Mounts Bambouto, West Cameroon," Agricultural Sciences, vol. 2, no. 3, pp. 334-340, 2011.

[22] L. Mueller, U. Schindler, W. Mirschel et al., "Assessing the productivity function of soils. A review," Agronomy for Sustainable Development, vol. 30, no. 3, pp. 601-614, 2010.

[23] P. Deb, P. Debnath, A. F. Denis, and O. T. Lepcha, "Variability of soil physicochemical properties at different agroecological zones of Himalayan region: Sikkim, India," Environment, Development and Sustainability, vol. 21, no. 5, pp. 2321-2339, 2019.

[24] G. T. Yengoh and J. Ardö, "Crop yield gaps in Cameroon," Ambio, vol. 43, no. 2, pp. 175-190, 2014.

[25] K. D. Awasthe, B. R. Singh, and B. K. Sitaula, "Profile carbon and nutrient levels and management effect on soil quality indicators in the Mardi watershed of Nepal," Acta Agriculturae Scandinavica Section B-Soil and Plant, vol. 55, no. 3, pp. 192-204, 2005.

[26] M. Budak, "Importance of spatial soil variability for land use planning of a farmland in a semi arid region," Fresenius Environmental Bulletin, vol. 27, no. 7, pp. 5053-5065, 2018.

[27] Cameroon's Annual Statistics, "National institute of statistics," 2017, http://www.statisticscameroon.org/news.php?id=513.

[28] V. Ngachie, "A general assessment of soil resources and soil fertility constraints in Cameroon on the basis of FAOUNESCO soil map analysis," Tropicultura, vol. 10, no. 2, pp. 61-63, 1992.

[29] S. D. Basga, J. P. Temga, D. Tsozué, N. Danbé, and J. P. Nguetnkam, "Morphological, mineralogical and geochemical features of topomorphic vertisols used for sorghum production in North Cameroon," Eurasian Journal of Soil Science (EJSS), vol. 7, no. 4, pp. 346-354, 2018.

[30] E. O. McLean, "Soil pH and lime requirement," in Methods of Soil Analysis, Part 2. Agronomy Monogr 9, A. L. Page, Ed., pp. 199-223, ASA and SSSA, Madison, WI, USA, 2nd edition, 1982.

[31] E. E. Schulte and B. G. Hopkins, "Estimation of soil organic matter by weight Loss-On-Ignition," in Soil Organic Matter: Analysis and Interpretation, F. R. Magdoff, M. A. Tabatabai, and E. A. Hanlon, Eds., pp. 21-32, Soil Science Society of America, . Madison, WI, USA, 1996. 
[32] A. Mehlich, "Mehlich 3 soil test extractant: a modification of Mehlich 2 extractant," Communications in Soil Science and Plant Analysis, vol. 15, no. 12, pp. 1409-1416, 1984.

[33] F. Laekemariam, K. Kibebew, and H. Shiferaw, "Potassium (K)-to-magnesium $(\mathrm{Mg})$ ratio, its spatial variability and implications to potential Mg-induced K defciency in Nitisols of Southern Ethiopia," Agriculture and Food Security, vol. 7, no. 1, p. 13, 2018.

[34] D. Ross, "Recommended soil tests for determining exchange capacity," in Recommended Soil Testing Procedures for the Northeastern United States. Northeastern Regional Bulletin \#493. Ag Experiment Station, J. T. Sims and A. Wolf, Eds., pp. 62-69, University of Delaware, Newark, DE, USA, 1995.

[35] R. H. Bray and L. T. Kurtz, "Determination of total, organic, and available forms of phosphorus in soils," Soil Science, vol. 59, no. 1, pp. 39-46, 1945.

[36] P. O. Phil-Eze, "Variability of soil properties related to vegetation cover in a tropical rainforest landscape," Journal of Geography and Regional Planning, vol. 3, no. 7, pp. 177-184, 2010.

[37] F. Laekemariam and K. Kibret, "Explaining soil fertility heterogeneity in smallholder farms of southern Ethiopia," Applied and Environmental Soil Science, vol. 2020, Article ID 6161059, 16 pages, 2020.

[38] G. A. Asongwe, B. P. K. Yerima, and A. S. Tening, "Spatial variability of selected physico-chemical properties of soils under vegetable cultivation in urban and peri-urban wetland gardens of Bamenda municipality, Cameroon," Africa Journal of Agricultural Research, vol. 11, no. 2, pp. 74-86, 2016.

[39] C. A. Cambardella and D. L. Karlen, "Spatial analysis of soil fertility parameters," Precision Agriculture, vol. 1, no. 1, pp. 5-14, 1999.

[40] Soil Survey Staff, "Soil survey laboratory methods manual," in Soil Survey Investigations Report No. 42, Version 5.0, R. Burt, Ed., pp. 276-279, U.S. Department of Agriculture, Natural Resource Conservation Service, Washington, DC, USA, 5th edition, 2014.

[41] S. O. Oshunsanya, Introductory Chapter: Relevance of Soil $p H$ to Agriculture, Soil $p H$ for Nutrient Availability and Crop Performance, IntechOpen, London, UK, 2018, https://www. intechopen.com/books/soil-ph-for-nutrient-availability-andcropperformance/introductory-chapter-relevance-of-soil-phto-agriculture.

[42] M. L. Fernandez Marcos, E. Alvarez, and C. Monterroso, "Aluminium and iron estimated by mehlich-3 extractant in mine soils in Galicia, northwest Spain, communication in," Soil Science and Plant Analysis, vol. 29, no. 5-6, pp. 599-612, 1998.

[43] T. S. Tran, M. Giroux, J. Guilbeault, and P. Audesse, "Evaluation of Mehlich-III extractant to estimate the available P in Quebec soils," Communications in Soil Science and Plant Analysis, vol. 21, no. 1-2, pp. 1-28, 1990.

[44] A and L Canada Laboratories, Fact Sheet No. 549, Revised 11/ 2013, A and L Canada Laboratories, London, ON, Canada, 2013, http://www.alcanada.com.

[45] M. L. E. Imakumbili, E. Semu, J. M. R. Semoka, A. Abass, and G. Mkamilo, "Soil nutrient adequacy for optimal cassava growth, implications on cyanogenic glucoside production: a case of Konzo affected Mtwara region, Tanzania," PLoS One, vol. 14, no. 5, Article ID e0216708, 2019.

[46] H. Ibrikci, J. Ryan, A. C. Ulger et al., "Maintenance of phosphorus fertilizer and residual phosphorus effect on corn production," Nutrient Cycling in Agroecosystems, vol. 72, no. 3, pp. 279-286, 2005.
[47] H. Y. Ch'ng, O. H. Ahmed, and N. M. A. Majid, "Improving phosphorous availability in an acid soil using organic amendments produced from agro industrial wastes," The Scientific World Journal, vol. 2014, p. 6, Article ID 506356, 2014.

[48] USDA-NRCS, Inherent Factors Affecting Soil Phosphorus, USDA-NRCS, Washington, DC, USA, 1994.

[49] J. R. Landon, Booker Tropical Soil Manual: A Handbook for Soil Survey and Agricultural Land Evaluation in the Tropics and Subtropics, Routledge, New York, NY, USA, 2014.

[50] J. R. Heckman, Soil Fertility Test Interpretation, Phosphorus, Potassium, Magnesium, and Calcium, Rutgers Cooperative Research \& Extension, New Jersey Agricultural Experiment Station Rutgers, The State University of New Jersey, New Brunswick, Canada, 1998.

[51] B. R. Hoskins, Soil Testing Handbook for Professionals in Agriculture, Horticulture, Nutrient and Residuals Management, Maine Forestry \& Agricultural Experiment Station, University of Maine, Orono, ME, USA, 3rd edition, 1997.

[52] H. Hailu, T. Mamo, R. Keskinen, E. Karltun, H. Gebrekidan, and T. Bekele, "Soil fertility status and wheat nutrient content in vertisol cropping systems of central highlands of Ethiopia," Agriculture \& Food Security, vol. 4, no. 1, p. 19, 2015.

[53] F. Laekemariam, "Soil nutrient status of smallholder cassava farms in Southern Ethiopia," Journal of Biology, Agriculture and Healthcare, vol. 6, no. 17, pp. 4-10, 2016.

[54] H. Wassie, "On farm verification of potassium fertilizer effect on the yield of Irish potato grown on acidic soils of Hagere Selam, Southern Ethiopia," Ethiopian Journal of Natural Resources, vol. 11, no. 2, pp. 207-221, 2009.

[55] V. Loide, "About the effect of the contents and ratios of soil's available calcium, potassium and magnesium in liming of acid soils," Agronomy Research, vol. 2, no. 1, pp. 71-82, 2004.

[56] I. O. Osemwota, J. A. I. Omueti, and A. I. Ogboghodo, "Effect of calcium/magnesium ratio in soil on magnesium availability, yield, and yield components of maize," Communications in Soil Science and Plant Analysis, vol. 38, no. 19-20, pp. 2849-2860, 2007.

[57] E. E. Schulte and K. A. Kelling, Soil Calcium to Magnesium Ratio- Should You BE Concerned?, University of Wisconsin Extension Bulletin G2986, Madison, WI, USA, 1985.

[58] J. Zbíral, M. Smatanová, and P. Němec, "Sulphur status in agricultural soils determined using the Mehlich 3 method," Plant Soil and Environment, vol. 64, pp. 255-259, 2018.

[59] J. Zbíral, "Determination of plant-available micronutrients by the Mehlich 3 soil extractant - a proposal of critical values," Plant, Soil and Environment, vol. 62, no. 11, pp. 527-531, 2016.

[60] D. Bitondo, F. O. Tabi, S. S. A. Kengmegne, M. Ngoucheme, and A. D. MvondoZe, "Micronutrient concentrations and environmental concerns in an intensively cultivated typic Dystrandept in Mount Bambouto, Cameroon," Open Journal of Soil Science, vol. 4, no. 6, pp. 283-288, 2013.

[61] D. J. Langsi, E. N. Nukenine, C. N. Fokunang, C. Suh, A. W. Agwanande, and T. H. Katamsadan, "Evaluation of post harvest maize treatment, phyto-insecticide use on maize varieties in Mezam division," International Journal of Agronomy and Agricultural Research, vol. 10, no. 3, pp. 1-17, 2017.

[62] E. Njukwe, O. Onadipe, D. A. Thierno et al., "Cassava processing among smallholder farmers in Cameroon: opportunities and challenges," International Journal of Agricultural Policy and Research, vol. 2, no. 4, pp. 113-124, 2014. 
[63] E. Ngonkeu, L. Tandzi, C. Dickmi et al., "Identification of farmer's constraints to maize production in the humid forest zone of Cameroon," Journal of Experimental Agriculture International, vol. 15, no. 3, pp. 1-9, 2017.

[64] C. J. Quezada-Crespo, M. D. Carrillo-Zenteno, F. L. MoralesIntriago, and R. A. Carrillo-Alvarado, "Nutrient critical levels and availability in soils cultivated with peach palm (Bactris gasipaes Kunth.) in Santo Domingo de Los Tsachilas, Ecuador," Acta Agronomica, vol. 66, no. 2, pp. 235-240, 2017.

[65] J. W. Wendt, "Evaluation of the Mehlich 3 soil extractant for upland Malawi soils," Communications in Soil Science and Plant Analysis, vol. 26, no. 5-6, pp. 687-702, 1995.

[66] B. Salami and T. E. Sangoyomi, "Soil fertility status of cassava fields in South Western Nigeria," American Journal of Experimental Agriculture, vol. 3, no. 1, pp. 152-164, 2013.

[67] C. Sys, E. Van Ranst, J. Debaveye, and F. Beernaert, Land Evaluation. Part III: Crop Requirements, Agricultural Publications No 7, G.A.D.C., Brussels, Belgium, 1993.

[68] R. H. Howeler, "Diagnosis of nutritional disorders and soil fertility maintenance of cassava," in Tropical Tuber Crops: Problems, Prospects and Future Strategies, G. T. Kurup, Ed., pp. 181-193, Oxford and IBH Publishing Co. Pvt. Ltd., New Delhi, India, 1996.

[69] R. H. Howeler, "Mineral nutrition of cassava," in Mineral Nutrient Disorders of Root Crops in the Pacific. Proc. Workshop, Held in Nuku'alofa, Kingdom of Tonga, E. T. Craswell, C. J. Asher, and J. N. O'Sullivan, Eds., pp. 110-116, ACIAR Proc. No. 5, Canberra, Australia, 1996.

[70] R. H. Howeler, Sustainable Soil and CropManagement of Cassava in Asia-A Reference Manual, CIAT Publication no. 389, CIAT, Cali, Colombia, 2014.

[71] R. S. Mylavarapu, J. F. Sanchez, J. H. Nguyen, and J. M. Bartos, "Evaluation of Mehlich-1 and Mehlich-3 extraction procedures for plant nutrients in acid mineral soils of Florida," Communications in Soil Science and Plant Analysis, vol. 33, no. 5-6, pp. 807-820, 2002.

[72] A. Kahsay, M. Haile, G. Gebresamuel, M. Mohammed, and M. Tejada Moral, "Land suitability analysis for sorghum crop production in northern semi-arid Ethiopia: application of GIS-based fuzzy AHP approach," Cogent Food \& Agriculture, vol. 4, no. 1, Article ID 1507184, 2018.

[73] M. Ahmed and D. N. Jeb, "Land suitability for sorghum using multi-criteria evaluation (MCE) and analytical hierarchy process (AHP) in Bunkure Kano state, Nigeria," IOSR Journal of Agriculture and Veterinary Science, vol. 7, no. 9, pp. 25-37, 2014.

[74] C. Trostle, Soil Fertility and Plant Nutrition for Grain Sorghum, Chapter 7, pp. 746-6101, Extension Agronomist, Lubbock, TX, USA, 806.

[75] N. J. Grundon, D. G. Edwards, P. N. Takkar, C. J. Asher, and R. B. Clark, Nutritional Disorders of Grain Sorghum. Monograph Series No. 2, Australian Center for International Agricultural Research (ACIAR), Canberra, Australia, 1987.

[76] M. Nathan, P. Scharf, Y. Sun, and D. Dunn, Evaluating Mehlich III Extractant for Extracting Available Nutrients for Missouri Soils Using Inductively Coupled Plasma Spectrometry Report for Year, Taylor \& Francis, Milton Park, UK, 2005.

[77] A. Soltanghei, Z. A. Rahman, C. F. Ishak, H. M. Musa, and H. Zakikhani, "Interaction effects of phosphorus and zinc on their uptake and 32P absorption and translocation in sweet corn (Zea mays var. Saccharata) grown in a tropical soil," Asian Journal of Plant Sciences, vol. 13, no. 3, pp. 129-135, 2014.
[78] P. Hazelton and B. Murphy, Interpreting Soil Test Results: What Do All the Numbers Mean, CSIRO, Canberra, Australia, 2nd edition, 2007.

[79] K. Zajícová and T. Chuman, "Effect of land use on soil chemical properties after 190 years of forest to agricultural land conversion," Soil and Water Research, vol. 14, no. 3, pp. 121-131, 2019.

[80] A. C. Hamilton, M. Takashi, and L. A. Fernando, "Relationship between acidity and chemical properties of Brazilian soils," Scientia Agricola, vol. 60, pp. 337-343, 2003.

[81] B. T. Nguyen, T. K. Do, T. V. Tran et al., "High soil Mn and Al, as well as low leaf $\mathrm{P}$ concentration, may explain for low natural rubber productivity on a tropical acid soil in Vietnam," Journal of Plant Nutrition, vol. 41, no. 7, pp. 903-914, 2018.

[82] P. B. Hoyt and M. Nyborg, "Use of dilute calcium chloride for the extraction of plant-available aluminum and manganese from acid soil," Canadian Journal of Soil Science, vol. 52, no. 2, pp. 163-167, 1972. 